\title{
Fiscal Stimulus to the Rescue? Short-Run Benefits and Potential Long- Run Costs of Fiscal Deficits
}

\author{
Charles Freedman, Michael Kumhof, \\ Douglas Laxton, Dirk Muir, \\ Susanna Mursula
}




\title{
IMF Working Paper
}

Research Department

Fiscal Stimulus to the Rescue?

Short-Run Benefits and Potential Long-Run Costs of Fiscal Deficits

\author{
Prepared by Charles Freedman, Michael Kumhof, Douglas Laxton, Dirk Muir and \\ Susanna Mursula ${ }^{1}$
}

November 2009

\begin{abstract}
This Working Paper should not be reported as representing the views of the IMF. The views expressed in this Working Paper are those of the author(s) and do not necessarily represent those of the IMF or IMF policy. Working Papers describe research in progress by the author(s) and are published to elicit comments and to further debate.
\end{abstract}

This paper uses the IMF's Global Integrated Monetary and Fiscal Model to compute shortrun multipliers of fiscal stimulus measures and long-run crowding-out effects of higher debt. Multipliers of two-year stimulus range from 0.2 to 2.2 depending on the fiscal instrument, the extent of monetary accommodation and the presence of a financial accelerator mechanism. A permanent 0.5 percentage point increase in the U.S. deficit to GDP ratio raises the U.S. tax burden and world real interest rates in the long run, thereby reducing U.S. and rest of the world output by $0.3-0.6$ and 0.2 percent, respectively.

JEL Classification Numbers:E62; F41; F42; H30; H63

Keywords: Fiscal Stimulus; Crowding-Out; Financial Crisis; Non-Ricardian Households; Government Deficits; Government Debt; Macro-Financial Linkages

Authors' E-Mail_ cfreedma@connect.carleton.edu, mkumhof@imf.org, Addresses: $\quad$ dlaxton@imf.org, dmuir@imf.org, smursula@imf.org

\footnotetext{
${ }^{1}$ We thank Olivier Blanchard, Charles Collyns and Jorg Decressin for encouraging us to do this work.
} 


\section{Contents}

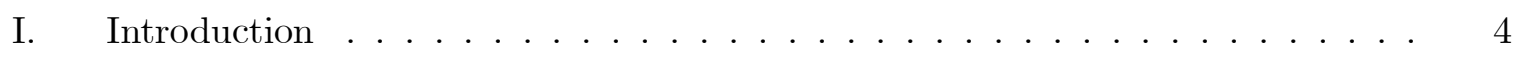

II. Literature Review . . . . . . . . . . . . . . . . . 6

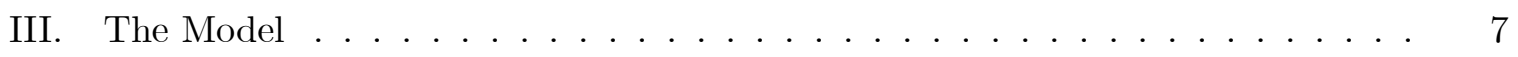

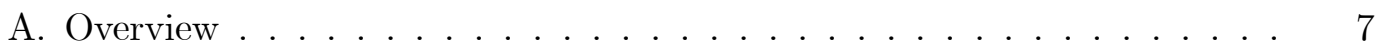

B. Households . . . . . . . . . . . . . . . . . . . 9

1. Overlapping Generations $(O L G)$ Households . . . . . . . . . . 9

2. Liquidity-Constrained $(L I Q)$ Households and Aggregate Households 12

C. Firms . . . . . . . . . . . . . . . . . . . . . 12

1. General Comments . . . . . . . . . . . . . . . . . . . 12

2. Entrepreneurs and Banks . . . . . . . . . . . . . . . . 12

D. Governmental Authorities . . . . . . . . . . . . . . . . 13

1. Budget Constraint . . . . . . . . . . . . . . . . 13

2. Fiscal Policy . . . . . . . . . . . . . . . . . . 13

3. Monetary Policy . . . . . . . . . . . . . . . . . . . . 14

E. Calibration . . . . . . . . . . . . . . . . . . . . 14

IV. Two Important Shocks and the Financial Accelerator . . . . . . . . . . . . . . 15

A. Decline in Productivity Growth . . . . . . . . . . . . . . . 16

B. Increase in Borrower Riskiness . . . . . . . . . . . . . . . 18

V. Short-Run Fiscal Multipliers . . . . . . . . . . . . . . . . . . 19

A. Increase in Government Investment Expenditures . . . . . . . . . . 20

B. Increase in General Lump-Sum Transfers . . . . . . . . . . . . . . . . 21

C. Increase in Targeted Lump-Sum Transfers . . . . . . . . . . . . . . . . 22

D. Decrease of the Labor Income Tax Rate . . . . . . . . . . . . . . . . . 22

VI. Effects of Announced G20 Fiscal Stimulus Packages . . . . . . . . . . . . . 23

VII. Long-Run Effects of the Accumulation of Public Debt . . . . . . . . . . . 23

VIII. Concluding Remarks . . . . . . . . . . . . . . . . . . . . . . . . 25

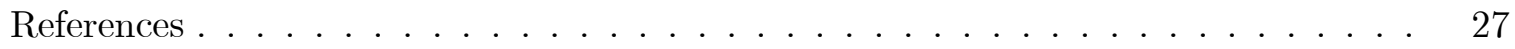

Figures

1. WEO Revisions to US GDP, Inflation and Interest Rates since April 2007 . . 30

2. United States: Net Worth, Liabilities, and Risky Spread . . . . . . . . . . 31

3. U.S. Persistent Productivity Growth Shock (Deviation from Baseline) . . . . . 32

4. U.S. Persistent Increase in Borrower Riskiness (Deviation from Baseline) . . . 33

5. U.S. Fiscal Stimulus, Instrument=Gov't Investment (Deviation from Baseline) 34

6. U.S. Fiscal Stimulus, Instrument=General Transfers (Deviation from Baseline) 35

7. U.S. Fiscal Stimulus, Instrument=Targeted Transfers (Deviation from Baseline) 36

8. U.S. Fiscal Stimulus, Instrument=Labor Income Tax (Deviation from Baseline) 37

9. Dynamic Effects of a 10 Percentage Point Increase in the Debt to GDP Ratio 38 
Tables

1. GDP Effects of G-20 Fiscal Stimulus (Percent Deviation from Baseline) . . . . 39

2. Effects of a Permanent 10 Percentage Point Increase in the U.S. Government Debt to GDP Ratio (Deviation from Baseline) . . . . . . . . . . . . 40 


\section{Introduction}

During the last two years, the global economy has been hit with large negative shocks that resulted from sharp declines in house and stock prices and a tightening of financial conditions. Figure 1 compares the forecasts for real GDP, inflation, and interest rates in the U.S. economy in the pre-crisis April 2007 IMF World Economic Outlook (WEO) with the actual outcomes to date as well as the forecast for the next few years in the October 2009 WEO. $^{2}$ The latter projects a path with a considerably lower level of real GDP than had been forecast in the pre-crisis WEO and a somewhat lower growth rate in the medium run. The forecast of a lower level of GDP reflects the destruction of physical and human capital during the crisis, in the financial sector and in a number of industrial sectors, such as the automotive industry. The reduction in the projected GDP growth rate is the result of a recognition that the earlier consensus view had overstated the trend rate of growth of potential output.

The financial crisis and the economic downturn fed on each other, with the problems in the financial sector causing weaknesses in the real sector and the deterioration in the real sector having negative consequences for the financial sector. The top panel of figure 2 shows the decline from about mid-2007 in the value of housing equity and nonfarm business net worth (in trillions of dollars), while the middle panel shows the ratio of liabilities to net worth (or leverage ratio) for both sectors and for the total of the two. From a starting point of about $75 \%$ in early 2006 , the leverage ratio in the housing sector rose to a peak of about $140 \%$ in early 2009 and that of nonfarm business rose to about $100 \%$ in mid-2009. The combined figure was about $110 \%$ in mid-2009. The decline in net worth and the increase in the leverage ratio played an important role in the increase in the cost of external financing in the U.S. economy during the crisis. The bottom panel of the figure sets out one measure of the spread between risky and riskless obligations, the difference between the corporate BAA rate and the 10-year government bond yield, as a proxy for the increase in the external finance premium over the crisis period. From about 1.7 percentage points in mid-2006 (somewhat below the more normal 2 percentage points), the spread increased to about 3 percentage points in mid-2008 and a peak of 6 percentage points at the end of 2008 before falling back appreciably over 2009 to about 3 percentage points currently.

Governments and central banks responded to financial sector difficulties by introducing a number of substantive and innovative measures to deal with liquidity and solvency problems in financial institutions and financial markets. In addition, central banks reduced interest rates to unprecedented levels to offset the increase in private sector risk premia and to underpin aggregate demand, and used nonconventional measures in the form of quantitative easing and qualitative or credit easing to bring about reductions in risk premia and to provide liquidity to markets in difficulty. In spite of these efforts, credit remained tight and aggregate demand in many countries weakened rapidly. There were negative spillovers from the weakening economies to those that had appeared to be more robust, and increased concern that the global economy might be moving into a period of deep and prolonged recession (IMF, 2009).

\footnotetext{
${ }^{2}$ The published April 2007 WEO projections were extended from 2012 to 2014 by assuming that they were moving towards their long-run steady state values. The actual Fed Funds rates in the figure are monthly data and their projected values for 2010 and 2011 come from the Fed Funds futures market.
} 
Governments around the world therefore went beyond monetary policy measures by introducing large stimulative fiscal packages. In this context, questions were raised about the effectiveness of temporary fiscal policy actions in lessening the depth and duration of the slowdown, and about the potential long-run negative effects on the economy of the debt accumulation resulting from the fiscal stimulus.

In this paper, we use the IMF's Global Integrated Monetary and Fiscal (GIMF) model, a dynamic stochastic general equilibrium model, to simulate the joint effects of fiscal and monetary stimulus measures. GIMF is a multi-region model of the world economy, with 5 regions in this paper's application. For the productive sector it features a conventional set-up, except for the presence of a financial accelerator mechanism. But for the effects of fiscal stimulus the critical aspect of GIMF is the household sector, which has two non-Ricardian features that affect both the short-run effectiveness of stimulus and the extent of long-run crowding-out due to government debt. First, a share of households is liquidity-constrained as in Gali and others (2007), that is these households are constrained to consume their after-tax income in every period. This has a strong effect on the short-run multiplier effects of tax and transfer based stimulus measures. Second, the remaining households have finite horizons as in Blanchard (1985), which implies that higher government debt has a non-zero net worth and will therefore crowd out physical capital and foreign asset holdings in the long run. In contrast, infinite horizon models rule out by construction the negative long-run effects on the economy of an accumulation of government debt.

There are many advantages to using a fully structural model such as GIMF to analyze the effects of the current set of policy measures. First, it allows for the short-run interaction of fiscal and monetary policy actions, especially the implications of the economy being at the zero interest rate floor in the presence of fiscal stimulus. Second, it also allows for an analysis of the long-run implications of policy actions, and of the dynamics between the short run and the long run. Third, it can be used to highlight how the effectiveness of fiscal stimulus depends on key structural characteristics of the economy, such as the proportion of households that are liquidity-constrained, the distortionary effects of different kinds of taxes, and the size of automatic stabilizers. ${ }^{3}$

The paper is structured as follows. Section 2 presents a brief literature review. Section 3 presents an overview of the GIMF model. Section 4 compares the results of shocks in two versions of GIMF, one with a financial accelerator and the other without, in order to assess how the introduction of macro-financial linkages affects the model simulations of key shocks. Section 5 uses the model, with and without a financial accelerator, to examine the short-run multipliers of various types of stimulative fiscal measures. Section 6 presents the simulated effects on the world economy of the actually announced G20 fiscal stimulus measures. Section 7 sets out the long-run effects of a permanent increase in the ratio of government debt to GDP, and discusses the transition between the short run and the long run. Section 8 provides some concluding comments.

\footnotetext{
${ }^{3}$ See, for example, Freedman and others (2009a,b)
} 


\section{Literature Review}

The recent debate on fiscal stimulus has to be seen against the background of a long debate in economics on the virtues or otherwise of fiscal activism. This debate centered mostly on the desirability of ongoing fine-tuning of the business cycle, while the current debate is taking place against the background of an exceptionally severe crisis, where even staunch opponents of the active and continuous use of fiscal policy have suggested that fiscal stimulus should be used as a one-off emergency measure. Nevertheless, in both cases the effectiveness of fiscal stimulus depends on the presence or absence of the same type of transmission mechanism.

Keynesian demand management through fine-tuning of fiscal policy was popular among economists of the 1950s and 1960s. ${ }^{4}$ But it started to be challenged by the emerging neoclassical school in the 1960s. ${ }^{5}$ There was a simultaneous challenge to the systematic use of monetary policy (Lucas (1972)), but here the pendulum started to swing back in favor of activism in the early 1980s, based on much improved theoretical and empirical foundations. ${ }^{6}$ But the presumption was still that policy activism should be left to monetary policy. It was argued (Gramlich (1999)) that it is critical that fiscal policy deliver its stimulus in a "timely, targeted and temporary" (TTT) manner, while experience showed this to be hard to achieve. But Solow (2005) and Wyplosz (2005) argue that this can be overcome through institutions and procedures that would allow fiscal policy to adopt the core principles of monetary policy.

Fiscal rules are one way to formalize the use of fiscal policy for fine-tuning the business cycle. Taylor (2000) discusses the desirability of a fiscal rule in which the budget surplus depends on the output gap, but he argues against its use because the Fed would only suffer from having to forecast the fiscal stance. He therefore argues, along with many other commentators at that time, that the role of fiscal policy should be limited to minimizing distortions and to "letting automatic stabilizers work". Automatic stabilizers describes channels through which policy can be mildly countercyclical even if fiscal instruments are not varied at all in response to the business cycle.

Crucially however, Taylor (2000) makes two exceptions to his assessment. The first is fixed exchange rate regimes, where monetary policy deliberately gives up its stabilizing role. The second is the type of situation the world economy faces today, where nominal interest rates approach their zero lower bound so that discretionary monetary policy becomes much more difficult. This, and the exceptional gravity of the current crisis, are the major reasons for the renewed interest in fiscal policy even among commentators who would still categorically reject the use of fiscal policy under more ordinary circumstances. ${ }^{7}$

\footnotetext{
${ }^{4}$ See Philips (1954), Musgrave (1959) and Tobin (1972). Similar ideas have been proposed more recently by Seidman (2003).

${ }^{5}$ See Eisner (1969), which was based on Friedman (1957), and Barro (1974).

${ }^{6}$ Key theoretical papers include Taylor (1980), Rotemberg (1982) and Calvo (1983), Taylor (1993) and Bernanke and Mishkin (1997).

${ }^{7}$ We would add that in an economy with many liquidity-constrained agents fiscal activism may be desirable even under flexible exchange rates and away from the zero bound. This is because monetary policy operates mainly through an intertemporal substitution channel that is absent for liquidity-constrained agents. Fiscal policy can directly affect these agents' income. See Kumhof and Laxton (2009a).
} 
The question then turns to how we should think about the short-run and long-run effects of the current stimulus packages in terms of a rigorous theoretical model. Until recently progress with the development, and even more so the acceptance, of models that admit a meaningful role for fiscal policy has been slow. Theoretical work in the $1990 \mathrm{~s}^{8}$ and even more recently focused almost exclusively on the study of optimal taxation that minimizes tax wedges in models with few or no rigidities. Not surprisingly, this analysis finds little benefit from time variation in taxes and spending.

Any attempt to go beyond this should start from the new generation of open economy monetary business cycle models, which have become very widely used both in academia and in policy-making institutions. However, as argued in several important papers, these model face difficulties in adequately replicating the dynamic short-run effects of fiscal policy such as those of stimulus. ${ }^{9}$ They also have serious shortcomings when applied to the analysis of longer-run fiscal issues such as the crowding-out effects of a permanent increase in fiscal deficits and public debt. ${ }^{10}$

To design a model that at least allows for the possibility of non-trivial stimulus and crowding-out effects, a critical departure from much of the existing literature has to be the incorporation of non-Ricardian household and firm behavior into a monetary business cycle model. We do so in this paper, using both liquidity-constrained agents that are critical for the short-run effects of fiscal policy, and finite-horizon agents that are critical for long-run crowding-out. To assess the strength of those effects, we then subject the model to a thorough sensitivity analysis.

\section{The Model}

This section, to conserve space, contains only a relatively brief overview of the model, followed by some details that are critical to understanding its fiscal policy implication. A complete description can be found in Kumhof, Laxton, Muir and Mursula (2009), henceforth KLMM. Time periods represent years.

\section{A. Overview}

The world consists of 5 regions, the United States (US), the euro area (EU), Japan (JA), emerging Asia $(\mathrm{AS})^{11}$ and remaining countries (RC). Region specific variables and parameters will be denoted by an index z where necessary. The regions trade with each other at the levels of intermediate and final goods, with a matrix of bilateral trade flows that is calibrated on recent historical averages. International asset trade is limited to nominally non-contingent bonds denominated in U.S. dollars. When bilateral goods or asset trade between one region and the United States is described, we will refer to U.S. quantities by a superscript asterisk. The world economy's technology grows at the constant rate $g=T_{t} / T_{t-1}$, where $T_{t}$ is the level of labor augmenting world technology, and

\footnotetext{
${ }^{8}$ This is surveyed in Chari and Kehoe (1999).

${ }^{9}$ See Fatas and Mihov (2001), Blanchard and Perotti (2002), Gali and others (2007).

${ }^{10}$ See Kumhof and Laxton (2009b).

${ }^{11}$ AS comprises China, Hong Kong S.A.R. of China, India, Indonesia, Korea, Malaysia, Philippines, Singapore, and Thailand.
} 
world population grows at the constant rate $n$. To simplify the exposition we present the perfect foresight version of the model.

Each country is populated by two types of households, both of which consume final retailed output and supply labor to unions. First, there are liquidity-constrained households who do not have access to financial markets, and who consequently are limited to consuming their after tax income in every period, as in Galí and others (2007). ${ }^{12}$ The share of these agents in the population equals $\psi(\mathrm{z})$. In each period $N(\mathrm{z}) n^{t} \psi(\mathrm{z})\left(1-\frac{\theta}{n}\right)$ of such individuals are born, where $N(\mathrm{z})$ indexes absolute population sizes in period 0 .

Second, there are overlapping generations households with finite planning horizons as in Blanchard (1985). The share of these agents in the population equals $1-\psi(\mathrm{z})$, and in each period $N(z) n^{t}(1-\psi(\mathrm{z}))\left(1-\frac{\theta}{n}\right)$ of such individuals are born. Each of these agents faces a constant probability of death $(1-\theta)$ in each period, which implies an average planning horizon of $1 /(1-\theta) .{ }^{13}$ In addition to the probability of death households also experience labor productivity that declines at a constant rate $\chi<1$ over their lifetimes. ${ }^{14}$ Life-cycle income adds another powerful channel through which fiscal policies have non-Ricardian effects. Households of both types are subject to uniform labor income, consumption and lump-sum taxes. We will denote variables pertaining to these two groups of households by $O L G$ and $L I Q$.

Firms are managed in accordance with the preferences of their owners, myopic $O L G$ households, and they therefore also have finite planning horizons. Except for capital goods producers, entrepreneurs and retailers, they are monopolistically competitive and subject to nominal rigidities in price setting. ${ }^{15}$ Each country's primary production is carried out by manufacturers producing tradable and nontradable goods. Manufacturers buy capital services from entrepreneurs and labor from unions. Unions buy labor from households. Entrepreneurs buy capital from capital goods producers. They are subject to an external financing constraint and a capital income tax. Capital goods producers are subject to investment adjustment costs. Manufacturers sell to domestic and foreign distributors, the latter via import agents located abroad that price to their respective markets.

Distributors combine a public capital stock with nontradable goods and domestic and foreign tradable goods, subject to an import adjustment cost. Distributors sell to domestic and foreign consumption and investment goods producers, via import agents for foreign sales. Consumption and investment goods producers combine domestic and foreign output, again subject to an import adjustment cost. Consumption goods are sold to retailers and the government, while investment goods are sold to capital goods producers and the government. Retailers face real sales adjustment costs, which together with habit persistence in preferences generates inertial consumption dynamics.

\footnotetext{
${ }^{12}$ We follow Galí and others (2007) in referring to these households as liquidity-constrained. Other terms used in the literature are rule-of-thumb or hand-to-mouth agents.

${ }^{13}$ Galí and others (2007) interpret the complete inability to smooth consumption of their model's liquidityconstrained households as (among other possible interpretations) extreme myopia, or a planning horizon of zero. We adopt the same interpretation for the average planning horizon of the finite-horizon model. We therefore allow for the possibility that agents may have a shorter planning horizon than what would be suggested by their biological probability of death. See KLMM for a more detailed discussion.

${ }^{14}$ This stylized treatment of life-cycle income is made possible by the absence of explicit demographics in our model, which means that we only need the assumption of declining labor productivity to be correct for the average worker.

${ }^{15}$ We assume quadratic inflation adjustment costs as in Ireland (2001) and Laxton and Pesenti (2003), meaning that inflation rather than the price level is sticky.
} 
Asset markets are incomplete. There is complete home bias in government debt, which takes the form of nominally non-contingent one-period bonds denominated in domestic currency. The only assets traded internationally are nominally non-contingent one-period bonds denominated in U.S. dollars. There is also complete home bias in ownership of domestic firms. Equity is not traded, instead households receive lump-sum dividend payments.

In our derivations per capita variables are only considered at the level of disaggregated households. When the model's real aggregate variables, say $x_{t}$, are rescaled, we divide by the level of technology $T_{t}$ and by population, but for the latter we divide by $n^{t}$ only, meaning real figures are not in per capita terms but rather in absolute terms adjusted for technology and population growth. We use the notation $\check{x}_{t}=x_{t} /\left(T_{t} n^{t}\right)$, with the steady state of $\check{x}_{t}$ denoted by $\bar{x}$.

\section{B. Households}

\section{Overlapping Generations $(O L G)$ Households}

A representative $O L G$ household of age $a$ derives utility at time $t$ from consumption $c_{a, t}^{O L G}$ relative to the consumption habit $h_{a, t}^{O L G}$, and from leisure $\left(1-\ell_{a, t}^{O L G}\right)$ (where 1 is the time endowment). The lifetime expected utility of a representative household has the form

$$
\sum_{s=0}^{\infty}(\beta \theta)^{s}\left[\frac{1}{1-\gamma}\left(\left(\frac{c_{a+s, t+s}^{O L G}}{h_{a+s, t+s}^{O L G}}\right)^{\eta^{O L G}}\left(1-\ell_{a+s, t+s}^{O L G}\right)^{1-\eta^{O L G}}\right)^{1-\gamma}\right]
$$

where $\beta$ is the discount factor, $\theta<1$ determines the planning horizon, $\gamma>0$ is the coefficient of relative risk aversion, and $0<\eta^{O L G}<1$. As for money, we assume the cashless limit advocated by Woodford (2003). Consumption $c_{a, t}^{O L G}$ is given by a

Dixit-Stiglitz CES aggregate over retailed consumption goods varieties $c_{a, t}^{O L G}(i)$, with elasticity of substitution $\sigma_{R}$. The (external) consumption habit is given by lagged per capita consumption of $O L G$ households, which in turn equals lagged aggregate consumption divided by the size of this population group,

$$
h_{a, t}^{O L G}=\left(\frac{c_{t-1}^{O L G}}{N(1-\psi)}\right)^{v},
$$

and where $v$ parameterizes the degree of habit persistence.

A household can hold domestic bonds denominated in domestic currency, which are either issued by the domestic government, $B_{a, t}$, or by banks lending to nontradables and tradables entrepreneurs, $B_{a, t}^{N}+B_{a, t}^{T}$. They can also hold foreign bonds denominated in U.S. dollars, $F_{a, t}$. The nominal exchange rate vis-a-vis the U.S. dollar is $\mathcal{E}_{t}$. Gross nominal interest rates on domestic and foreign currency denominated assets held from $t$ to $t+1$ are $i_{t}$ and $i_{t}^{*}\left(1+\xi_{t}^{f}\right)$, where $i_{t}^{*}$ is the U.S. dollar nominal interest rate and $\xi_{t}^{f}$ is a foreign exchange risk premium that is external to the household's asset accumulation decision.

Participation by households in financial markets requires that they enter into an insurance contract with companies that pay a premium of $\frac{(1-\theta)}{\theta}$ on a household's financial wealth for 
each period in which that household is alive, and that encash the household's entire financial wealth in the event of his death. ${ }^{16}$

$O L G$ households' pre-tax nominal labor income is $W_{t} \Phi_{a, t} \ell_{a, t}$. The productivity of an individual household's labor declines throughout his lifetime, with productivity $\Phi_{a, t}$ of age group $a$ given by $\Phi_{a, t}=\Phi_{a}=\kappa \chi^{a}$, where $\chi<1$. OLG households also receive lump-sum remuneration for their services in the bankruptcy monitoring of entrepreneurs, $P_{t} r b r_{a, t}$. Lump-sum after-tax nominal dividend income received from firm/union $i$ in sector $j$ are denoted by $D_{a, t}^{j}(i)$.

$O L G$ households' labor income is taxed at the rate $\tau_{L, t}$ and consumption is taxed at the rate $\tau_{c, t}$. In addition there are lump-sum taxes $\tau_{a, t}^{l s}$, and transfers $\Upsilon_{a, t}^{O L G}$ paid to/from the government. ${ }^{17}$ The consumption tax $\tau_{c, t}$ is payable on the price $P_{t}$ at which retailers purchase final consumption goods from distributors. We choose $P_{t}$ as our numeraire. Actual sales by retailers are conducted at the price $P_{t}^{R}$.

The real wage is $w_{t}=W_{t} / P_{t}$, the price level, relative price and gross inflation rate of any good $x$ are $P_{t}^{x}, p_{t}^{x}=P_{t}^{x} / P_{t}$ and $\pi_{t}^{x}=P_{t}^{x} / P_{t-1}^{x}$, gross final consumption goods inflation is $\pi_{t}=P_{t} / P_{t-1}$, and gross nominal exchange rate depreciation and the level of the real exchange rate vis-a-vis the United States are $\varepsilon_{t}=\mathcal{E}_{t} / \mathcal{E}_{t-1}$ and $e_{t}=\left(\mathcal{E}_{t} P_{t}^{*}\right) / P_{t}$. Real domestic bonds are $b_{t}=B_{t} / P_{t}$ and real internationally traded bonds are $f_{t}=F_{t} / P_{t}^{*}$. The real interest rate in terms of final consumption goods is $r_{t}=i_{t} / \pi_{t+1}$. Letting the index $j$ denote the different firm/union sectors of the model, the household's budget constraint in nominal terms is

$$
\begin{gathered}
P_{t}^{R} c_{a, t}^{O L G}+P_{t} c_{a, t}^{O L G} \tau_{c, t}+P_{t} \tau_{a, t}^{l s}+B_{a, t}+B_{a, t}^{N}+B_{a, t}^{T}+\mathcal{E}_{t} F_{a, t} \\
=\frac{1}{\theta}\left[i_{t-1}\left(B_{a-1, t-1}+B_{a-1, t-1}^{N}+B_{a-1, t-1}^{T}\right)+i_{t-1}^{*} \mathcal{E}_{t} F_{a-1, t-1}\left(1+\xi_{t-1}^{f}\right)\right] \\
+W_{t} \Phi_{a, t} \ell_{a, t}^{O L G}\left(1-\tau_{L, t}\right)+\sum_{j} \int_{0}^{1} D_{a, t}^{j}(i) d i+P_{t} r b r_{a, t}+P_{t} \Upsilon_{a, t}^{O L G} .
\end{gathered}
$$

The household maximizes (1) subject to (3). We obtain standard first-order conditions for the consumption/leisure choice. Uncovered interest parity is given by $i_{t}=i_{t}^{*} \xi_{t} \varepsilon_{t+1}$.

A key condition the model is the optimal aggregate consumption rule of $O L G$ households. ${ }^{18}$ Consumption is a function of real aggregate financial wealth $f w_{t}$ and human wealth $h w_{t}^{L}+h w_{t}^{K}$, with the marginal propensity to consume of out of wealth given by $1 / \Theta_{t}$, with $h w_{t}^{L}$ representing the present discounted value of households' time endowments evaluated at the after-tax real wage, and $h w_{t}^{K}$ representing the present discounted value of capital or dividend income net of lump-sum transfer payments to the government. After rescaling by technology we have

\footnotetext{
${ }^{16}$ The turnover in the population is assumed to be large enough that the income receipts of the insurance companies exactly equal their payouts.

${ }^{17}$ It is convenient to keep these two items separate in order to account for a country's overall fiscal accounts, and to allow for targeted transfers to $L I Q$ agents.

${ }^{18}$ Aggregation takes account of the initial size of each age cohort and the remaining size of each generation. For consumption we have $c_{t}^{O L G}=N(1-\psi) n^{t}\left(1-\frac{\theta}{n}\right) \Sigma_{a=0}^{\infty}\left(\frac{\theta}{n}\right)^{a} c_{a, t}^{O L G}$, and similarly for aggregate labor.
} 


$$
\check{c}_{t}^{O L G} \Theta_{t}=\check{f} w_{t}+\check{h} w_{t}^{L}+\check{h} w_{t}^{K}
$$

where

$$
\begin{gathered}
\text { where } \check{f}_{t}=\frac{1}{\pi_{t} g n}\left[i_{t-1}\left(\check{b}_{t-1}+\check{b}_{t-1}^{N}+\check{b}_{t-1}^{T}\right)+i_{t-1}^{*} \varepsilon_{t}\left(1+\xi_{t-1}^{f}\right) \check{f}_{t-1} e_{t-1}\right] \\
\check{h} w_{t}^{L}=\left(N(1-\psi)\left(\check{w}_{t}\left(1-\tau_{L, t}\right)\right)+\frac{\theta \chi g}{r_{t}} \check{h}_{t+1}^{L}\right. \\
\check{h} w_{t}^{K}=\left(\Sigma_{j} \check{d}_{t}^{j}+r \check{b}_{t}-\check{\tau}_{t}^{l s, O L G}+\check{\Upsilon}_{t}^{O L G}\right)+\frac{\theta g}{r_{t}} \check{h}_{t+1}^{K} \\
\Theta_{t}=\frac{p_{t}^{R}+\tau_{c, t}}{\eta^{O L G}}+\frac{\theta j_{t}}{r_{t}} \Theta_{t+1} \\
j_{t}=\left(\beta r_{t}\right)^{\frac{1}{\gamma}}\left(\frac{p_{t}^{R}+\tau_{c, t}}{p_{t+1}^{R}+\tau_{c, t+1}}\right)^{\frac{1}{\gamma}}\left(\chi g \frac{\check{w}_{t+1}\left(1-\tau_{L, t+1}\right)\left(p_{t}^{R}+\tau_{c, t}\right)}{\check{w}_{t}\left(1-\tau_{L, t}\right)\left(p_{t+1}^{R}+\tau_{c, t+1}\right)}\right)^{\left(1-\eta^{O L G}\right)\left(1-\frac{1}{\gamma}\right)}\left(\frac{\check{c}_{t}^{O L G} g}{\check{c}_{t-1}^{O L G}}\right)^{v \eta^{O L G}\left(1-\frac{1}{\gamma}\right)}
\end{gathered}
$$

The implication of this set of equations is that government debt adds to agents' net worth, that the time profile of tax changes affects the time profile of consumption, and that in the long run government debt crowds out private capital and net foreign assets. The intuition is as follows:

Financial wealth depends on the government's current financial liabilities, which are serviced through different forms of taxation. These future taxes are reflected in the different components of human wealth, as well as in the marginal propensity to consume. But unlike the government, which has an infinite planning horizon, a household with finite planning horizon attaches less importance to higher tax payments in the distant future, by discounting future tax liabilities at the rates $r_{t} / \theta$ and $r_{t} / \theta \chi$, which are higher than the market rate $r_{t}$. Government debt is therefore net wealth to the extent that households, due to short planning horizons, disregard the future taxes necessary to service that debt.

A fiscal stimulus through initially lower taxes, and accompanied by a permanent increase in debt, represents a tilting of the tax payment profile from the near future to the more distant future. The present discounted value of the government's future primary deficits has to remain equal to the current debt $i_{t-1} b_{t-1} / \pi_{t}$ when future deficits are discounted at the market interest rate $r_{t}$. But for households the same tilting of the tax profile represents an increase in human wealth because an increasing share of future taxes becomes payable beyond the household's planning horizon. For a given marginal propensity to consume, this increase in human wealth leads to an increase in consumption.

The intertemporal elasticity of substitution $1 / \gamma$, for the conventional assumption of $\gamma>1$, implies that the income effect of an increase in the real interest rate is stronger than the substitution effect and increases the marginal propensity to consume $1 / \Theta_{t}$. This partly offsets the contractionary effects of a higher real interest rate on human wealth. A larger $\gamma$ therefore requires larger interest rate changes to clear markets following fiscal shocks. 


\section{Liquidity-Constrained $(L I Q)$ Households and Aggregate Households}

The objective function of liquidity-constrained $(L I Q)$ households is assumed to be identical to that of $O L G$ households. These agents can consume at most their current income, which consists of their after tax wage income plus net government transfers. After rescaling by technology, their budget constraint is given by

$$
\check{c}_{t}^{L I Q}\left(p_{t}^{R}+\tau_{c, t}\right)=\check{w}_{t} \ell_{t}^{L I Q}\left(1-\tau_{L, t}\right)+\check{\Upsilon}_{t}^{L I Q}-\check{\tau}_{t}^{l s, L I Q}
$$

This group of households has a very high marginal propensity to consume out of income, so that fiscal multipliers of revenue based stimulus measures such as tax cuts and increases in transfers are particularly high whenever such agents have a high population share.

Aggregate consumption and labor supply are given by $\check{C}_{t}=\check{c}_{t}^{O L G}+\check{c}_{t}^{L I Q}$ and $\check{L}_{t}=\check{\ell}_{t}^{O L G}+\check{\ell}_{t}^{L I Q}$.

\section{Firms}

\section{General Comments}

To conserve space we only describe here the entrepreneur/bank sector of the financial accelerator, which solves a one period problem. KLMM contains the complete details for the other sectors. Each firm in those sectors maximizes the present discounted value of net cash flow or dividends. The discount rate it applies in this maximization includes the parameter $\theta$ so as to equate the discount factor of firms $\theta / r_{t}$ with the pricing kernel for nonfinancial income streams of their owners, $O L G$ households. The first-order conditions for optimal price setting and input choices are standard except for the presence of the term $\theta$ in the discount factor.

\section{Entrepreneurs and Banks}

This sector is based on the models of Bernanke and others (1999) and Christiano and others (2007). Entrepreneurs in the tradables and nontradables sectors purchase capital stocks from capital goods producers and rent them to manufacturers, after deciding on the level of capital utilization. Each entrepreneur finances his capital with a combination of his net worth and bank loans. Loans are risky because the productivity of an entrepreneur's capital is subject to idiosyncratic risk. The bank extends a loan contract to the entrepreneur, who is risk-neutral and therefore bears all aggregate risk. The loan contract specifies a loan amount and a state-contingent schedule of gross interest rates to be paid if productivity is above a cut-off level. Entrepreneurs below the cutoff go bankrupt and must hand over their entire capital stock to the bank. Due to monitoring costs $r b r_{t}$ the bank can only recover a fraction of the value of such firms. The bank finances its loans to entrepreneurs by borrowing from households. It pays households a nominal rate of return $i_{t}$ that is not state-contingent.

The parameters of the entrepreneur's debt contract are chosen to maximize entrepreneurial profits, subject to zero bank profits in each state of nature. Zero profits 
require that the non-stochastic payment to depositors must equal the stochastic payoff to lending in each state of nature. The latter includes the interest from non-bankrupt firms, plus the liquidation value of bankrupt firms, minus monitoring costs of bankrupt firms. Due to the costs of bankruptcy entrepreneurs must pay an external finance premium, which equals the difference between the rate paid by entrepreneurs to banks and the rate paid by banks to depositors.

Given that banks make zero profits at all times, the difference between the aggregate returns to capital net of bankruptcy costs and the sum of deposit interest paid by banks to households goes to entrepreneurs and accumulates. To rule out net worth accumulation to the point that entrepreneurs no longer need loans, we assume that they regularly pay out dividends to households according to a fixed dividend policy.

An important implication of this sector is an upward-sloping relationship between the external finance premium and entrepreneurs' debt to equity ratio or leverage. However, unlike in linearized versions of financial accelerator models where this (together with net worth evolution) is the only equation attributable to this sector, our model retains the full nonlinear setup. This generates important nonlinearities when shocks to net worth are large.

\section{Governmental Authorities}

\section{Budget Constraint}

Fiscal policy consists of a specification of consumption and investment spending $G_{t}=G_{t}^{c o n s}+G_{t}^{i n v}$, lump-sum taxes $\tau_{l s, t}=\tau_{t}^{l s, O L G}+\tau_{t}^{l s, L I Q}$, lump-sum transfers $\Upsilon_{t}=\Upsilon_{t}^{O L G}+\Upsilon_{t}^{L I Q}$, and tax rates $\tau_{L, t}, \tau_{c, t}$ and $\tau_{k, t}$.

Government consumption spending is unproductive, while government investment spending augments a stock of publicly provided infrastructure capital that depreciates at the rate $\delta_{G}$. Tax revenue $\tau_{t}$ is endogenous and given by the sum of labor, consumption, capital and lump-sum taxes. The government budget constraint is

$$
\check{b}_{t}=\frac{i_{t-1}}{\pi_{t} g n} \check{b}_{t-1}+\check{G}_{t}+\check{\Upsilon}_{t}-\check{\tau}_{t}=\frac{i_{t-1}}{\pi_{t} g n} \check{b}_{t-1}-\check{s}_{t}
$$

where $\check{s}_{t}$ is the primary surplus.

\section{Fiscal Policy}

A fiscal policy rule stabilizes deficits and the business cycle. First, it stabilizes the interest inclusive government deficit to GDP ratio $g d_{t}^{r a t}$ at a long-run level $g d s s^{r a t}$, thereby ruling out default and fiscal dominance. Second, it stabilizes the business cycle by letting the deficit fall with the output gap. We have

$$
g d_{t}^{r a t}=g d s s_{t}^{r a t}-d^{g d p} \ln \left(\frac{g \check{d} p_{t}}{g \check{d} p_{p o t}}\right) .
$$


Here $d^{g d p} \geq 0, g d_{t}^{r a t}$ is given by

$$
g d_{t}^{r a t}=100 \frac{\frac{\left(i_{t-1}-1\right) \check{b}_{t-1}}{\pi_{t} g n}-\check{s}_{t}}{g \check{d} p_{t}}=100 \frac{\check{b}_{t}-\frac{\check{b}_{t-1}}{\pi_{t} g n}}{g \check{d} p_{t}},
$$

and $g d s s_{t}^{r a t}$ is the long-run target (structural) government deficit to GDP ratio. Shocks to this target represent changes in government savings preferences. We denote the current value and the long-run target of the government debt to GDP ratio by $\check{b}_{t}^{\text {rat }}$ and $\breve{b} s s_{t}^{r a t}$. The relationship between $b s s_{t}^{r a t}$ and $g d s s_{t}^{r a t}$ follows directly from the government's budget constraint as

$$
b s s_{t}^{r a t}=\frac{\bar{\pi} g n}{\bar{\pi} g n-1} g d s s_{t}^{r a t},
$$

where $\bar{\pi}$ is the inflation target of the central bank. In other words, for a given trend nominal growth rate, choosing a deficit target $g d s s_{t}^{r a t}$ implies a debt target $\breve{b} s s_{t}^{r a t}$ and therefore keeps debt from exploding. We note that the implied long-run autoregressive coefficient on debt, at $1 /(\bar{\pi} g n)$, is quite close to one.

Our model allows for permanent shocks to technology and to private saving, which have permanent effects on potential GDP due to the non-Ricardian features of the model. Potential output $g \check{d} p_{p o t}$ is therefore modeled as an arithmetic moving average of past actual values of GDP to allow for the gap to close over time. Fiscal policy can typically be characterized by the degree to which automatic stabilizers work. This has been quantified by the OECD, who have produced estimates of $d^{g d p}$ for a number of countries. ${ }^{19}$

The rule (12) is not an instrument rule but rather a targeting rule. Any of the available tax and spending instruments can be used to make sure the rule holds. The default setting in this paper is that this instrument is general transfers $\check{\Upsilon}_{t}$, meaning transfers that are not specifically targeted at one of the two household groups.

\section{Monetary Policy}

Monetary policy uses an interest rate rule to stabilize inflation. The rule is similar to a conventional inflation forecast based rule that responds to one-year-ahead inflation, but with the important exception that the "steady state" of the real interest rate needs to be formulated as a (geometric) moving average, similar to potential output above.

\section{E. Calibration}

Detailed calibration tables are presented in KLMM. Here we comment only on the most important features.

The real per capita growth rate is 1.5 percent, the world population growth rate is 1 percent, and the long-run real interest rate is 3 percent.

Household utility functions are equal across countries. The intertemporal elasticity of substitution is 0.25 , or $\gamma=4$, and the wage elasticity of labor supply is 0.5 . The

\footnotetext{
${ }^{19}$ See Girouard and André (2005).
} 
parameters $\psi, \theta$ and $\chi$ are critical for the non-Ricardian behavior of the model. The shares of liquidity-constrained agents are 25 percent in US, EU and JA, and 50 percent in $\mathrm{AS}$ and $\mathrm{RC}$, reflecting less developed financial markets in the latter two regions. The average remaining time at work is 20 years, or $\chi=0.95$. The planning horizon is also equal to 20 years, or $\theta=0.95$. The main criterion used in choosing $\theta$ and $\chi$ is the empirical evidence of Laubach (2003), Engen and Hubbard (2004) and Gale and Orszag (2004) for the effect of government debt on real interest rates. They find that a one percentage point increase in the government debt to GDP ratio in the U.S. leads to an approximately one to six basis points long-run increase in the U.S. (and therefore world) real interest rate. Our calibration is at the lower end of that range, at around one basis point. Our estimates of the long-run crowding-out effects of higher fiscal deficits and debt are therefore very conservative.

As for technologies, elasticities of substitution equal 1 between capital and labor, 0.75 between domestic and foreign goods, and 0.5 between tradables and nontradables. Steady state gross markups equal 1.1 in manufacturing and wage setting, 1.05 in retailing, investment and consumption goods production, and 1.025 for import agents.

Steady state GDP decompositions, trade flows and debt ratios are based on recent historical averages.

For the public capital stock accumulation we adopt Kamps' (2004) 4 percent per year estimate of $\delta_{G}$. Ligthart and Suárez (2005) estimate the elasticity of aggregate output with respect to public capital at 0.14 . This is reproduced by our model through specifying the productivity of public capital in the distribution sector's technology.

Calibration of the financial accelerator sector is, with some exceptions, based on Christiano and others (2007) and Bernanke and others (1999). We fix two key ratios. First, leverage, defined as the ratio of corporate debt to corporate equity, equals 100 in all sectors and regions. Second, the steady state external finance premium equals 2.5 percent.

The calibration of monetary rule parameters is conventional for an annual model. For fiscal rule parameters the calibration assumes target deficit to GDP ratios consistent with historically observed government debt to GDP ratios. We use OECD estimates of output gap coefficients $d^{g d p}$.

This paper compares, throughout its discussion of simulation results, a version of GIMF without a financial accelerator with an alternative that adds separate financial accelerator sectors in tradables and nontradables production. The calibration of the two model variants is kept identical in all sectors that are common to both models.

\section{Two Important Shocks and the Financial Accelerator}

We begin by illustrating the importance of including a financial accelerator mechanism in the model. We do so using two shocks that in our view reflect important aspects of recent economic events, a decline in the potential growth rate of the U.S. economy and an increase in the project riskiness of the U.S. corporate sector. The latter shock is only 
present in the version of the model with a financial accelerator. We assume that both shocks are temporary but highly persistent.

The key feature of the financial accelerator is that firms need to borrow to finance their holdings of physical capital, and that in doing so they face an external finance premium that is increasing in leverage, defined as the ratio of debt to net worth. Thus, when net worth declines, the real interest rate faced by the corporate sector increases. And shocks to net worth have persistent effects because it takes several years to rebuild lost net worth.

Corporate net worth is equal to the market value of the firm's physical capital minus the value of the firm's financial liabilities. The value of physical capital can be adversely affected by negative technology shocks, by higher bankruptcy costs, by higher riskiness of corporate borrowers (either for idiosyncratic reasons or in response to the increased riskiness of the economy as a whole) and by an increase in the rate of depreciation of the capital stock. The value of outstanding nominal indebtedness can rise due to a decline in the price level.

A deterioration in corporate balance sheets through one of these shocks affects the rest of the economy through two main channels. First, higher leverage increases the external finance premium and thereby reduces investment. Second, lower earnings and the necessity to rebuild lost net worth lead to lower dividend distributions to households, which reduces income, wealth and consumption.

The monetary policy response to adverse shocks, and also to the fiscal stimulus response to such shocks, has played a key role in the recent policy debate. ${ }^{20}$ Several of the world's main central banks have reached the zero lower bound on nominal interest rates during the course of the financial crisis, and are therefore unable to further mitigate the effects of negative shocks through lower rates. This means that further falls in inflation cause real interest rates to rise far more quickly than in ordinary circumstances. Our simulations, in this section and throughout the paper, reflect these circumstances by comparing three sets of environments, ranging from an ordinary monetary policy response that follows an interest rate reaction function, to a situation where the central bank keeps nominal interest rates unchanged for two years. The interaction between the financial accelerator mechanism and the response or non-response of interest rates to shocks plays a critical role for the magnitude of our results.

\section{A. Decline in Productivity Growth}

Figure 3 illustrates in detail the effects on the U.S. and rest of the world economies of a temporary but persistent reduction in productivity growth in the United States. The shock involves a reduction in the rate of sector-wide productivity growth of 0.25 percentage points for 10 years in both the tradables and non-tradables sectors, followed by a return to the baseline rate of growth. ${ }^{21}$

\footnotetext{
${ }^{20}$ See, for example, Freedman and others (2009a).

${ }^{21}$ In both this shock and the shock in the next subsection, changes in the deficit are financed by changes in general transfers, and automatic stabilizers function in the normal way.
} 
The top four rows of the figure show the effects of the shock on real GDP, inflation, the nominal interest rate, the real interest rate, consumption and investment in the United States for the models without and with a financial accelerator. Row 4 also shows the movements in corporate net worth and the external finance premium for the model with a financial accelerator, variables that do not exist in the model without a financial accelerator. Rows 5 and 6 present a subset of these variables for the rest of the world (RW), without and with a financial accelerator.

In figure 3 and in all subsequent figures, the red line reflects the effects of the shock when the policy interest rate can drop immediately in response to a contractionary shock, in line with the monetary policy reaction function. The blue line involves a situation in which policy rates are left unchanged for one year following the contractionary shock, either because the policy interest rate is at the zero interest rate floor (ZIF) for the year or because of a delay in the policy response. The green line involves a situation with policy rates left unchanged for two years, because the policy interest rate is at the zero interest rate floor (ZIF) or delayed for both years.

Consider the productivity shock in the model without a financial accelerator (rows 1, 3 and 5 in figure 3) and with interest rates able to adjust in line with the monetary policy reaction function (red line). The short-run to medium-run effects of the decline in productivity growth are a reduction in real GDP and a decline in inflation. The latter indicates that aggregate demand falls by more than aggregate supply over the time period shown in the figure, as households anticipate the reduction in lifetime income by immediately reducing consumption expenditures, and as businesses reduce their investment expenditures appreciably in response to the anticipated lower productivity growth. The central bank gradually reduces the policy interest rate, and the real interest rate eventually falls below baseline.

Next consider the case of interest rates unchanged for one year (blue line). With real interest rates in the first year above that in the previous case, real GDP, inflation, consumption and investment are slightly lower than in that case. With interest rates held fixed for two years (green line), the inability of monetary policy to offset the downward pressure on the economy for a prolonged period, and the consequent substantial rise in the real interest rate, are associated with considerably larger declines in real GDP, inflation, consumption and investment.

As can be seen in row 5 , in the model without a financial accelerator there are only limited spillovers from the shock in the U.S. economy to consumption and investment expenditures in the rest the world, even in the case of unchanged nominal interest rates for two years. Real GDP barely moves, as the appreciation in the U.S. dollar related to the rise in U.S. real interest rates results in a strengthening of the trade balance in the rest of the world.

Now consider the productivity shock in the model with a financial accelerator (rows 2,4 and 6 in figure 3). For the cases in which interest rates are able to adjust or are fixed for only one year, introducing the financial accelerator causes the negative effects of the shock to be slightly larger. In the case of interest rates fixed for two years, in contrast, introducing a financial accelerator causes a substantial increase in the negative effects of the shock. There are two principal mechanisms responsible for this outcome. 
First, the results in the model with a financial accelerator are affected by the substantial increase in the external finance premium. The reason is higher leverage due to lower net worth, which in turn results from a combination of the negative effect of lower productivity growth on the market value of physical capital with the positive effect of the unanticipated fall in the price level on the real value of outstanding debt. Investment expenditures are negatively affected by the higher external finance premium, while consumption expenditures fall in response to lower dividend distributions from the corporate sector, due to both lower earnings and the effort to rebuild lost net worth.

Second, the larger decline in investment and consumption expenditures results in a decline in real GDP and inflation, thereby raising the riskless real interest rate still further, especially for the case of nominal interest rates fixed for two years. A higher riskless real interest rate further drives down investment and, through a reduction in lifetime wealth, consumption expenditures.

The interaction of all these factors results, for the case of interest rates unchanged for two years, in a decline in consumption expenditures of about 2.5 percent in the model with a financial accelerator compared with less than 1.5 percent in the model without a financial accelerator, and a reduction of 4.5 percent in investment expenditures in year two in the model with a financial accelerator compared with about 2 percent in the model without a financial accelerator.

Introducing a financial accelerator into the model has little effect on the RW in the cases of interest rates able to adjust or held unchanged for one year. In contrast, in the case of interest rates held fixed for two years, the spillovers to the rest of the world are considerably higher than in the model without a financial accelerator, with the larger effects showing up in both investment and consumption expenditures. These increased downward movements are not the direct result of demand spillovers from lower spending in the United States, which are fairly small, as is common in this type of model. Rather, they are the result of much stronger propagation of whatever spillovers do exist. Specifically, the decline in U.S. demand reduces inflation not only in the United States but also in RW. Under monetary accommodation this drives up RW real interest rates, thereby negatively affecting corporate balance sheets and external finance premia.

In sum, an inability of monetary policy to moderate, through lower interest rates, the contractionary effects of the shock on the economy and on inflation lead to much larger effects on the factors that drive the external finance premium and therefore greatly intensify the effects of the shock both in the United States and in the rest of the world.

\section{B. Increase in Borrower Riskiness}

Figure 4 presents the effects of a temporary but persistent increase in the idiosyncratic project risk of corporate borrowers in the United States, in both the tradables and non-tradables sectors. The shock is specified to gradually phase out over time, with an annual decay factor of 0.95 . The figure maintains symmetry with the previous and subsequent figures by maintaining the same layout and omitting the model without financial accelerator, in which this shock is not present. 
The shock results in an increase of between 70 and 90 basis points in the external finance premium in year one, depending on the ability of nominal interest rates to adjust to the shock. While this increase has some effect on consumption and a very considerable and persistent effect on investment even in the cases of interest rates that are able to adjust or are fixed for one year, the effects are much larger in the case of unchanged interest rates for two years. Part of the increase in the effects in the latter case can be attributed to the larger initial movement in the external finance premium, but most is attributable to the much greater increase in the riskless real interest rate. For this shock, spillovers to RW are miniscule for the cases of interest rates able to adjust or fixed for one year, but very significant for the case of interest rates unchanged for years, for the same reasons as were explained in the previous subsection.

\section{Short-Run Fiscal Multipliers}

This section turns to an evaluation, and comparison across different possible policy environments, of one of the two key aspects of recently adopted fiscal policy measures, their effectiveness at stimulating aggregate demand and output in the short run. Section 7 will consider the other aspect, the possibility of a large run-up in government debt that can have very harmful effects in the longer run.

We discuss simulations for four types of temporary fiscal stimulus measures-(i) an increase in government investment expenditures; (ii)an increase in general lump-sum transfers to all households; (iii) an increase in lump-sum transfers targeted specifically at liquidity-constrained households; and (iv) a decrease in tax rates on labor income. ${ }^{22}$ In all cases, the fiscal shock involves discretionary stimulative actions equal to 1 percent of pre-shock GDP for two years. The resulting government deficits are smaller than the size of the shock because automatic stabilizers $\left(d^{g d p}>0\right)$ react to the positive movements of GDP that result, directly and indirectly, from the discretionary fiscal actions.

In our discussions of the results we will use the terminology "fiscal multiplier" to describe the size of the GDP effects of the four stimulus measures. Given that the stimulus equals exactly one percent of baseline GDP in the first two years, the fiscal multiplier equals simply the percentage change in GDP for those same years.

Fiscal stimulus has effects on both the demand and the supply side of the economy. The demand effects come from the fiscal action feeding directly into aggregate demand (in the case of government investment expenditures), or from increasing real disposable incomes that partly result in higher spending (in the case of increases in general or targeted transfers and decreases in tax rates on labor income). The magnitude of the effect on aggregate demand of higher real disposable incomes in the case of an increase in general transfers will depend on the proportion of households that are liquidity-constrained, since such households will spend a much higher share of the increase in their disposable income than will $O L G$ households. All of these demand effects will have the usual secondary multiplier effects, as the recipients of higher spending (in the form of increased labor incomes and dividends) in turn increase their spending.

\footnotetext{
${ }^{22}$ See Freedman and others (2009b) for a more detailed discussion of fiscal multipliers that also includes government consumption expenditures, consumption taxes and corporate income taxes.
} 
For some stimulus measures important supply-side effects also have to be considered. Government investment expenditure on infrastructure increases potential output over time, which affects the gap between aggregate demand and potential output. And temporary decreases in distortionary taxes on labor income result in an increase in the supply of labor (and therefore an increase in potential output). In both cases, one important consequence will be a reduction in the inflationary effects of fiscal stimulus.

As in the previous section, we allow for the possibilities of interest rates adjusting in line with the monetary policy reaction function and interest rates unchanged for one or two years. In the case of expansionary fiscal measures, we will refer to this as no monetary accommodation and monetary accommodation for one or two years. Monetary accommodation plays a critical supportive role for all four fiscal stimulus measures considered here. Stimulus increases inflationary pressures (or at least reduces deflationary pressures), which under constant nominal interest rates lowers the real interest rate, thereby giving rise to further increases in consumption and investment expenditures. Furthermore, lower real interest rates cause real exchange rates to depreciate, which can also play a role in stimulating aggregate demand.

Figures 5 to 8 present the effects of the four types of temporary U.S. fiscal actions. As before, the figures distinguish between model versions without and with a financial accelerator, and between different degrees of monetary accommodation.

\section{A. Increase in Government Investment Expenditures}

Figure 5 shows the effects of an increase in government investment expenditures. The average effects on U.S. GDP over the two years of fiscal stimulus in the model without a financial accelerator are sizeable, ranging from a 1.2 percent increase in GDP without monetary accommodation, to 1.4 percent for one year of monetary accommodation, to 1.8 percent for two years of monetary accommodation. The corresponding effects in the model with a financial accelerator are 1.3 percent, 1.5 percent, and 2.2 percent.

There are a number of reasons for the relatively large multipliers of government investment expenditures. First, government investment feeds directly into aggregate demand. Second, it has a small but appreciable effect on aggregate supply, by making

private production more efficient. Third, under monetary accommodation, the substantial increase in inflation leads to an appreciable decline in real interest rates. For example, with two-year monetary accommodation and a financial accelerator, riskless real interest rates are below baseline by around 1.2 percentage points in years 1 and 2 . The result is a significant increase in private sector investment and consumption expenditures, to go along with the increase in government investment expenditures.

With a financial accelerator, corporate net worth increases as the strengthening economy raises the market value of physical capital, and as higher inflation reduces the real value of corporate debt, thereby causing a reduction in the external finance premium, especially in the case of two-year monetary accommodation. This leads to an additional reduction in interest rates faced by corporate borrowers, over and above that from the decline in the riskless real interest rate, and therefore to even larger investment expenditures. 
As will be seen in all the fiscal actions, the degree of monetary accommodation plays a crucial role in the size of the fiscal effects. More precisely, it is the combination of accommodation and the initial direct effect of the fiscal action on spending and hence on inflation that gives rise to the movements in real interest rates that support and greatly increase, by more than 50 percent, the direct effects of the fiscal action on GDP.

The effects of fiscal stimulus on realized fiscal deficits is of course also a matter of great interest to policymakers. We find that the effects of stimulus on deficits are offset to a considerable extent by automatic stabilizers, especially in the case of monetary accommodation. Indeed, in the case of a shock to government investment in the context of two years of monetary accommodation and a financial accelerator, the fiscal accounts move back into balance in year 3. Moreover, in this case the government debt to GDP ratio is well below baseline for several years, as the effect of the relatively small deficits in the first two years is offset by the increase in real GDP, and by the effect of the rise in prices on the real value of government debt. However, the deliberate use of inflation as an ongoing mechanism to bring down the debt to GDP ratio would in reality have additional effects that are not captured by the model. Most notably, it could lead to increases in interest rate risk premia if markets perceived that the government intends to monetize the debt. Such interest rate movements would counter the downward tendency in the debt-to-GDP ratio.

The effects on the rest of the world of the U.S. fiscal stimulus are small in the case of no monetary accommodation and one-year monetary accommodation, whether or not there is a financial accelerator in the model. However, with two years of monetary accommodation, spillovers result in a much larger increase in real GDP (about 0.6 percent on average over the two years) in the model with a financial accelerator than in the model without a financial accelerator (about 0.3 percent).

\section{B. Increase in General Lump-Sum Transfers}

The effects on GDP of an increase in general lump-sum transfers (figure 6) are small, even in the case of monetary accommodation. In the model without a financial accelerator and without monetary accommodation, GDP increases by less than 0.2 percent, with consumption rising somewhat and investment falling. The results are similar for one-year monetary accommodation. With two-year monetary accommodation, the results are somewhat larger, with real GDP rising by about 0.3 percent. There is virtually no spillover to the rest of the world.

The main reason for these small multipliers is that the increase in general lump-sum transfers will only have a significant effect on the spending of liquidity-constrained households, who comprise only one quarter of the U.S. household population. The other three quarters of U.S. households treat most of the increase in income as a two-year windfall, and will spend only a small proportion of the increase, in line with the small increase in their wealth that results from the temporary increase in transfers. Because of the small size of the initial increase in demand, there are only very small secondary effects. The indirect effect from the decline in real interest rates under monetary accommodation is also minimal since there is such a small increase in inflation. 
Adding a financial accelerator to the model results in very small increases in the multiplier in the case of no monetary accommodation and one-year monetary accommodation, since the effects of the fiscal action on corporate net worth and the external finance premium are very small. In the case of two-year monetary accommodation, there are somewhat larger effects on corporate net worth and the external finance premium, and real GDP rises by about 0.4 percent on average over two years. Spillovers to the rest of the world are also more noticeable in the case with a financial accelerator and two-year monetary accommodation.

\section{Increase in Targeted Lump-Sum Transfers}

Targeted transfers are aimed directly at liquidity-constrained households, who have a very high marginal propensity to consume out of current income. When the one quarter of such households in the United States receive 100 percent of the increase in transfers, the aggregate increase in consumption is much higher than when they receive only 25 percent of the increase in transfers.

Figure 7 shows the results. The effects on U.S. GDP are almost four times larger than the effects of an increase in untargeted general lump-sum transfers. In the case of two-year monetary accommodation, they equal 1.1 percent compared with 0.3 percent in the model without a financial accelerator, and 1.5 percent compared with 0.4 percent in the model with a financial accelerator. The larger increase in U.S. demand for the case of targeted transfers results in significantly higher inflation not only in the United States but also, albeit less so, in RW. This relatively limited spillover is however propagated much more strongly in the presence of financial accelerator effects and monetary accommodation, as higher RW inflation drives down real interest rates, thereby positively affecting corporate balance sheets and external finance premia. The result is a significantly larger increase in GDP in the rest of the world than in the case of general lump-sum transfers, about four times as large in the case of two-year monetary accommodation and a financial accelerator.

\section{Decrease of the Labor Income Tax Rate}

The results of fiscal stimulus through a reduction in the labor income tax rate are presented in figure $8 .^{23}$ For both the models without and with a financial accelerator, the effect on U.S. GDP is slightly larger than in the case of general lump-sum transfers for no monetary accommodation and one-year monetary accommodation, and slightly smaller in the case of the two-year monetary accommodation. The reduction in labor income taxes increases the amount of labor supplied by households. Similar to the case of government investment expenditures, there are therefore two indirect effects operating in opposite directions. First, the increase in labor supply directly increases potential and actual output, and by more than for the case of general transfers. Second, as a result of the increase in potential GDP, there is less upward pressure on inflation and less downward pressure on the real interest rate, and therefore less monetary stimulus to aggregate

\footnotetext{
${ }^{23} \mathrm{~A}$ discretionary reduction of about 1.7 percentage points in the tax rate on labor income is needed to achieve a discretionary increase of 1 percent in the ratio of the government deficit to GDP.
} 
demand than for the case of general transfers. For example, in the case of two-year monetary accommodation and no financial accelerator, U.S. real interest rates fall on average by about 0.3 percentage points over the two years when the fiscal instrument is general lump-sum transfers, but they are virtually unchanged in the case of a reduction in taxes on labor income. A similar result holds in the model with a financial accelerator and two-year monetary accommodation. Given the much smaller changes in real interest rates, there is also less propagation due to financial accelerator effects on the external finance premium.

\section{Effects of Announced G20 Fiscal Stimulus Packages}

Table 1 sets out the simulated effects on regional and global GDP of the actually announced G20 fiscal stimulus packages that are being implemented over 2009 and 2010. We again use the model versions without and with a financial accelerator (top half and bottom half of table 1). ${ }^{24}$ Also, we make what appears from the current vantage point to be the most realistic assumption about monetary policy, namely two years of accommodation.

Japan, emerging Asia and the United States have announced the largest fiscal packages, while the G20 countries in the euro area, Africa and Latin America have smaller packages. In terms of their composition, general and targeted transfers dominate in Japan, government investment spending dominates in emerging Asia, general and targeted transfers and labor income taxes dominate in the United States, while in the euro area

and other countries there is a relatively large role for corporate income tax cuts in $2010 .{ }^{25}$ It is interesting to note that increases in government consumption expenditures do not play a predominant role in any of the regions, which validates our focus above on other types of fiscal stimulus.

Both versions of the model show a considerable impact on GDP of the announced fiscal stimulus packages. The regional decomposition reflects both the different sizes of the announced packages and the higher multipliers of government investment based measures (as in emerging Asia). But even packages that contain predominantly tax- and transfer-based measures have sizeable effects. Consistent with the earlier results on fiscal multipliers, the effects in the model with a financial accelerator are up to 50 percent larger. Once again, the difference comes from the favorable effects on corporate net worth and the external financing premium of the stimulus-induced improvement in the economy.

\section{Long-Run Effects of the Accumulation of Public Debt}

In this section, we assess the risks to the regional and global economies of the deficits associated with the fiscal stimulus measures becoming chronic and therefore leading to permanently higher debt. Specifically, we consider the effects of a permanent 0.5

\footnotetext{
${ }^{24}$ These are based on data collected by the staff of the IMF, as of April 20, 2009.

${ }^{25}$ Transfers that fall under the social safety net heading are treated as targeted transfers for simulation purposes.
} 
percentage point increase in the U.S. government deficit to GDP ratio, which ultimately results in a 10 percentage point increase in the U.S. government debt to GDP ratio. ${ }^{26} \mathrm{We}$ assume that the deficits are initially driven up by stimulus measures based on either higher lump-sum transfers or lower taxes on labor income, consumption expenditures, and capital income. As debt and real interest rates increase, transfers are lowered or taxes increased, but not sufficiently to reverse the 0.5 percentage point increase in deficits. We restrict attention to the model version with a financial accelerator.

Figure 9 illustrates the dynamic paths of key U.S. variables for the case of stimulus based on lower labor income tax rates. Automatic stabilizers are allowed to operate during the transition, but their effect is small because the government is assumed to quickly update its estimate of potential output following the shock. In the first 10 years following the increase in deficits, U.S. GDP, consumption, and investment increase. ${ }^{27}$ At the same time, the higher level of aggregate demand leads to a deteriorating trade balance and a real appreciation. Inflation and nominal interest rates rise, and so do real interest rates, except for the first two periods. During this initial phase, higher real interest rates are mostly associated with the monetary policy response to higher inflation.

In subsequent decades real GDP declines relative to baseline by ultimately about 0.4 percent. There are two reasons, one connected with real interest rates and the second with tax rates. First, higher fiscal deficits lead to lower U.S. saving and therefore, given the size of the U.S. economy, lower world saving. Given the non-Ricardian behavior of households, an increase in private saving only partly offsets the decline of public saving in the short and medium run, with the offset even smaller in the long run. The result is an increase in the world real interest rate that crowds out investment in U.S. physical capital and therefore real output. It also crowds out U.S. investment in net foreign assets, and because the current account and the net foreign asset position exhibit the same type of long-run relationship as government deficits and government debt in equation (14), it leads to a progressive deterioration in U.S. current account imbalances with the rest of the world. ${ }^{28}$ The rising interest payments to foreigners require a reversal of the initially negative trade balance, which in turn necessitates a depreciation of the real effective exchange rate, back to above the baseline level. The second reason for the long-run decrease in GDP is the evolution of U.S. distortionary labor income taxes. While they fall initially to cause the short-run stimulus effect on GDP, in the longer run they must rise above the baseline to service a larger stock of public debt that carries a higher real interest rate. In the long run, the U.S. fiscal actions have a significant negative effect on GDP in the other regions, as higher world real interest rates result in lower capital ratios and hence lower GDP in all regions.

While figure 9 focuses on the transitional dynamics of the above mentioned higher deficits and debt scenario, Table 2 concentrates only on its long-run GDP effects, broken down regionally into the United States, the rest of the world, and the global economy. Higher

\footnotetext{
${ }^{26}$ We choose the United States for illustrative purposes only. An identical increase in deficits in another region that accounts for a similar share of world GDP would have virtually the same effects on the world economy.

${ }^{27}$ Note that the short-run multipliers are not directly comparable to our earlier exercises. In those simulations the size of the stimulus was expressed as a fraction of pre-stimulus GDP, while here deficits are expressed as a fraction of actual post-stimulus GDP, which is larger.

${ }^{28}$ See Kumhof and Laxton (2009b) for a more detailed treatment of this issue.
} 
debt results in a decline in long-run U.S. real GDP of 0.27 percent for general transfers, 0.34 percent for consumption taxes, 0.43 percent for labor income taxes and 0.64 percent for taxes on capital income. The corresponding figures for global real GDP are 0.21 percent, 0.24 percent, 0.28 percent and 0.34 percent.

There are a number of factors behind these results. First, higher world real interest rates due to non-Ricardian household behavior crowd out investment and therefore potential output worldwide, thereby accounting for the globally negative GDP effects. Second, the U.S. results are worse for all instruments because, unlike the rest of the world, it has to finance a higher debt stock from higher distortionary taxes. ${ }^{29}$ Third, the more distortionary the tax, the greater the effect on potential GDP. ${ }^{30}$

We conclude that if fiscal stimulus should lead to permanently higher deficits and therefore debt, the consequences may look favorable for the domestic economy in the short run and even in the medium run, but at the expense of very unfavorable long-run consequences. The reason is that higher debt eventually leads to both higher distortionary taxes and higher real interest rates, with the latter spreading the negative effects to the global economy.

\section{Concluding Remarks}

This paper has used the IMF's macroeconomic DSGE model, GIMF, to analyze two key questions that have arisen during the recent policy debate on fiscal stimulus. First, how effective is fiscal stimulus in the short run? In other words, what is the multiplier of fiscal stimulus on GDP? Second, how damaging is fiscal stimulus in the long run if it becomes permanent? In other words, what are the long-run crowding-out effects of higher debt on GDP?

GIMF has been developed for several years precisely with questions of this nature in mind. It features non-Ricardian households whereby fiscal policy can have significant real effects in both the short run and the long run, and its specification allows for many different fiscal instruments. It embeds this in a monetary business cycle framework that allows for an analysis of the interaction of monetary and fiscal policies. And it adds a financial accelerator mechanism that gives an important role to macro-financial shocks and transmission channels, a critical aspect of the recent financial crisis.

The comprehensive nature of the model has a major advantage for the type of policy analysis undertaken in this paper - it allows us to explore the sensitivity of our conclusions to many different combinations of policies and structural features (such as the presence or absence of a financial accelerator mechanism). Most importantly, unlike monetary policy, fiscal policy can use a large number of different instruments, and there is no substitute for exploring them one at a time.

\footnotetext{
${ }^{29}$ The U.S. contraction is also larger for general transfers, because their eventual reduction leads to a redistribution from $L I Q$ to $O L G$ households.

${ }^{30}$ Yet another possible linkage between the ratio of public debt to GDP and long-run potential output would be an increase in the risk premium on the public debt in response to a rise in the ratio of debt to GDP because of concerns about the long-run sustainability of the fiscal path. This relationship is not included in the version of GIMF used in this paper.
} 
We find that the multipliers of a two-year fiscal stimulus package range from 1.3 for government investment to 0.2 for general transfers, with targeted transfers closer to the upper end of that range and tax cuts closer to the lower end. In the presence of monetary accommodation and a financial accelerator mechanism multipliers are up to twice as large, as accommodation lowers real interest rates, which in turn has a positive effect on corporate balance sheets and therefore on the external finance premium.

As for crowding-out, a permanent 0.5 percentage points increase in the U.S. deficit to GDP ratio leads to a 10 percentage points increase in the U.S. debt to GDP ratio in the long run. Servicing this higher debt raises the U.S. tax burden and world real interest rates in the long run, thereby eventually reducing U.S. output by between 0.3 and 0.6 percent, with the size of the output loss again depending on the distortionary effects of the fiscal instrument. These output losses are larger than the corresponding short-run stimulus effects for the same instruments. But much more importantly, they are also permanent. The real interest rate effect (but not the tax burden effect) affects the rest of the world equally and accounts for output losses of around 0.2 percent.

The foregoing suggests that a carefully chosen package of fiscal and supporting monetary stimulus measures can provide a significant contribution to supporting domestic and global economies during a period of acute stress. But such measures should also be embedded in a conservative medium-term fiscal framework which ensures that deficits and debt do not drift upwards permanently when the economy recovers. In the absence of such a framework the long-run costs would far exceed the short-run benefits. 


\section{References}

Barro, R.J. (1974), "Are Government Bonds Net Wealth?", Journal of Political Economy, 82(6), 1095-1117.

Bernanke, B.S., Gertler, M. and Gilchrist, S. (1999), "The Financial Accelerator in a Quantitative Business Cycle Framework", in: John B. Taylor and Michael Woodford, eds., Handbook of Macroeconomics, Volume 1C. Amsterdam: Elsevier.

Bernanke, B. and Mishkin, F. (1997), "Inflation Targeting: A New Framework for Monetary Policy?", Journal of Economic Perspectives, 11, 97-116.

Blanchard, O.J. (1985), "Debt, Deficits, and Finite Horizons", Journal of Political Economy, 93, 223-247.

Blanchard, O.J. and R. Perotti, 2002, "An Empirical Characterization of the Dynamic Effects of Changes in Government Spending and Taxes on Output", Quarterly Journal of Economics, 117 (4), 1329-1368.

Calvo, G.A. (1983), "Staggered Prices in a Utility-Maximizing Framework", Journal of Monetary Economics, 12, 383-398.

Chari, V.V. and Kehoe, P.J. (1999), "Optimal Fiscal and Monetary Policy”, Chapter 26 in Taylor, J.B. and Woodford, M., eds., Handbook of Macroeconomics, Volume 1C, Elsevier.

Christiano, L., Motto, R. and Rostagno, M. (2009), "Financial Factors in Business Cycles", Working Paper, Northwestern University and European Central Bank.

Eisner, R. (1969), "Fiscal and Monetary Policy Reconsidered", American Economic Review, 59, 897-905.

Engen, E.M. and R.G. Hubbard (2004), "Federal Government Debt and Interest Rates", NBER Macroeconomics Annual, 19, 83-138.

Fatas, A., and I. Mihov (2001), "The Effects of Fiscal Policy on Consumption and Employment: Theory and Evidence", CEPR Discussion Paper 2060.

Freedman, C., M. Kumhof, D. Laxton, and J. Lee (2009a), "The Case for Global Fiscal Stimulus", IMF Staff Position Paper No. 09/04 (Washington, DC.: International Monetary Fund).

Freedman, C., M. Kumhof, D. Laxton, D. Muir and S. Mursula (2009b), "Fiscal Multipliers Galore", forthcoming IMF Working Paper.

Friedman, M. (1957), A Theory of the Consumption Function, Princeton, NJ: National Bureau of Economic Research.

Gale, W. and P. Orszag (2004), "Budget Deficits, National Saving, and Interest Rates", Brookings Papers on Economic Activity, 2, 101-187. 
Galí, J., J.D. López-Salido and J. Vallés (2007), "Understanding the Effects of Government Spending on Consumption", Journal of the European Economic Association, 5(1), 227-270.

Girouard, N. and C. André (2005), "Measuring Cyclically-Adjusted Budget Balances for OECD Countries", OECD Economics Department Working Papers, No. 434, OECD Publishing.

Gramlich, E.M. (1999), "Remarks by Governor Edward M. Gramlich before the Wharton Public Policy Forum Series, Philadelphia, Pennsylvania".

International Monetary Fund (2009), "Global Economic Slump Challenges Policies", World Economic Outlook Update, January, World Economics and Financial Surveys (Washington).

Ireland, P. (2001), "Sticky-Price Models of the Business Cycle: Specification and Stability", Journal of Monetary Economics, 47, 3-18.

Kamps, C. (2004), "New Estimates of Government Net Capital Stocks for 22 OECD Countries 1960-2001", IMF Working Paper Series, WP/04/67.

Kumhof, M. and D. Laxton (2009a), "Simple, Implementable Fiscal Policy Rules", IMF Working Papers, WP/09/76.

Kumhof, M. and D. Laxton (2009b), "Fiscal Deficits and Current Account Deficits", IMF Working Papers, WP/09/237.

Kumhof, M., D. Laxton, D. Muir, and S. Mursula (2009), "The Global Integrated Monetary and Fiscal Model - Theoretical Structure", IMF Working Papers (forthcoming).

Laubach, T. (2003), "New Evidence on the Interest Rate Effects of Budget Deficits and Debt", Finance and Economics Discussion Series 2003-12, Board of Governors of the Federal Reserve System.

Laxton, D. and P. Pesenti (2003), "Monetary Rules for Small, Open, Emerging Economies", Journal of Monetary Economics, 50(5), 1109-1152.

Ligthart, J.E. and Suárez, R.M.M. (2005), "The Productivity of Public Capital: A Meta Analysis", Working Paper, Tilburg University.

Lucas, R.E. (1972), "Expectations and the Neutrality of Money", Journal of Economic Theory, 4, 103-124.

Musgrave, R.A. (1959), The Theory of Public Finance, New York: McGraw Hill.

Philips, A.W. (1954), "Stabilization Policy in a Closed Economy", Economic Journal, 64, 290-332.

Rotemberg, J. (1982), "Sticky Prices in the United States", Journal of Political 
Economy, 90, 1187-1211.

Seidman, L.S. (2003), Automatic Fiscal Policies to Combat Recessions, Armonk, NY: M.E. Sharpe.

Solow, R.M. (2005), "Rethinking Fiscal Policy", Oxford Review of Economic Policy, 21(4), 509-514.

Taylor, J.B. (1980), "Aggregate Dynamics and Staggered Contracts", Journal of Political Economy, 88, 1-24.

Taylor, J.B. (1993), "Discretion versus Policy Rules in Practice", Carnegie-Rochester Conference Series on Public Policy, 39, 195-214.

Taylor, J.B. (2000), "Reassessing Discretionary Fiscal Policy", Journal of Economic Perspectives, 14(3), 21-36.

Tobin, J. (1972), The New Economics One Decade Older, Princeton, N.J.: Princeton University Press.

Woodford, M. (2003), Interest and Prices: Foundations of a Theory of Monetary Policy. Princeton: Princeton University Press.

Wyplosz, C. (2005), "Fiscal Policy: Institutions versus Rules", National Institute Economic Review, 191, 70-84. 
Figure 1: WEO Revisions to US GDP, Inflation and Interest Rates since April 2007
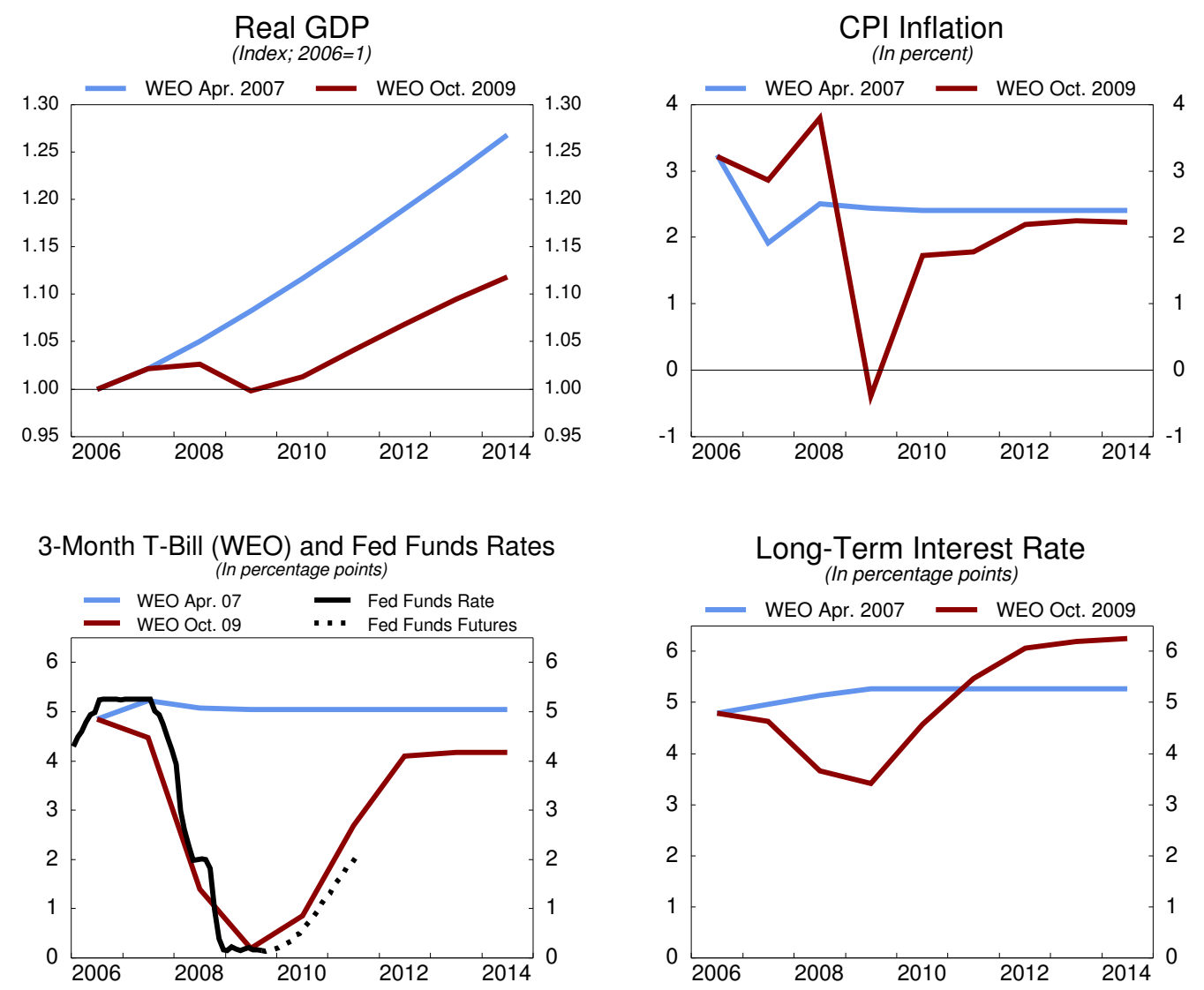
Figure 2: United States: Net Worth, Liabilities, and Risky Spread

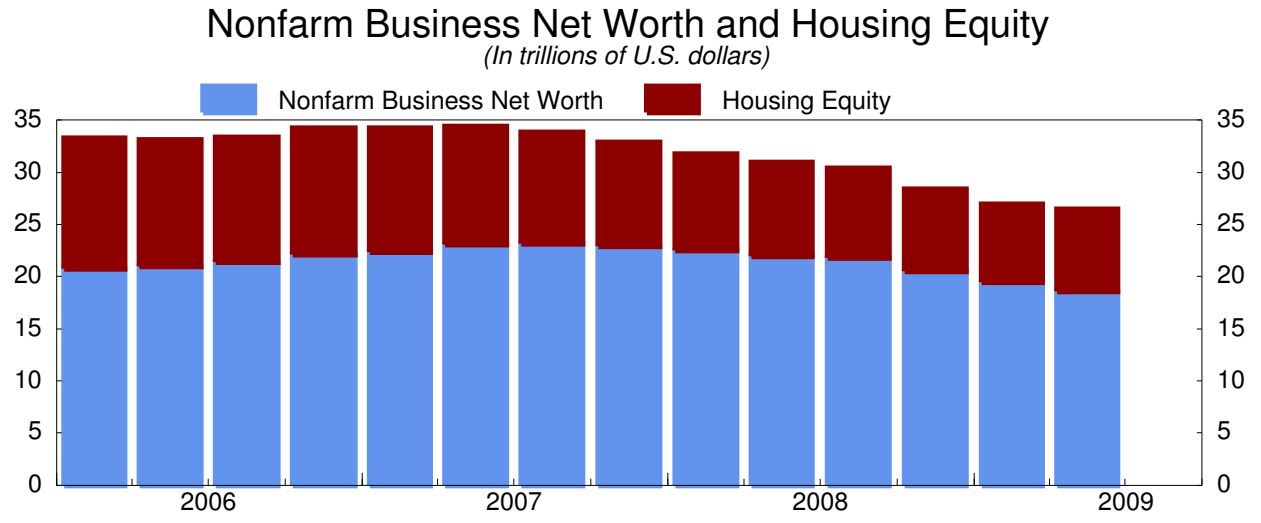

Liabilities to Net Worth Ratio (In percent)

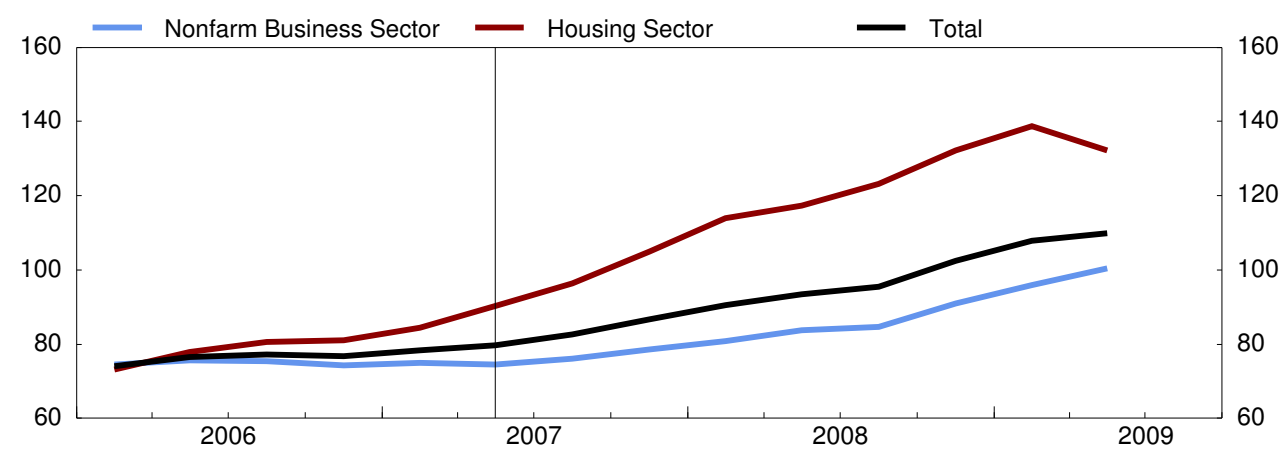

Risky Spread: Difference Between Corporate BAA and 10-Year Government Bond Yield

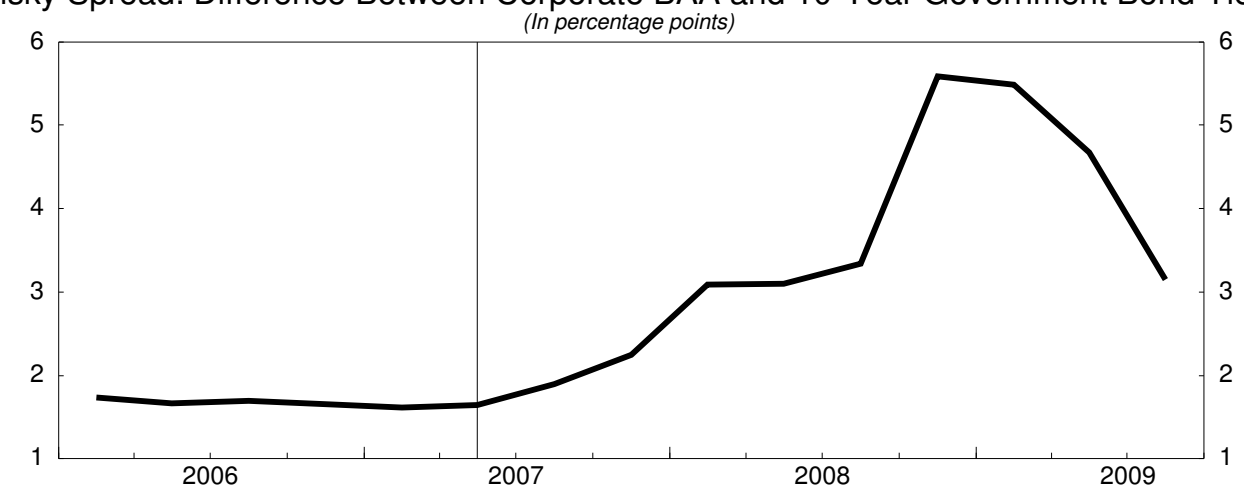


Figure 3: U.S. Persistent Productivity Growth Shock (Deviation from Baseline)
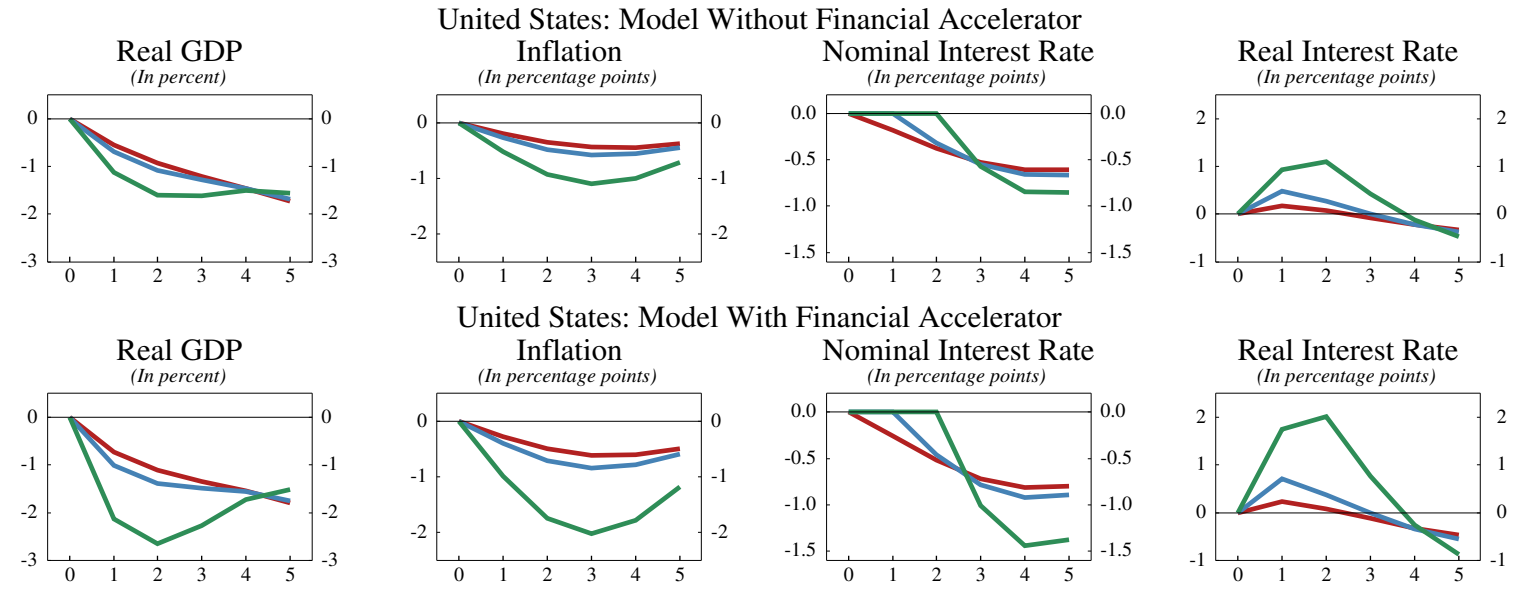

United States: Model Without Financial Accelerator

Consumption

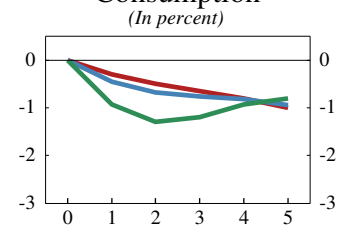

United States: Model With Financial Accelerator

External Financing Premium
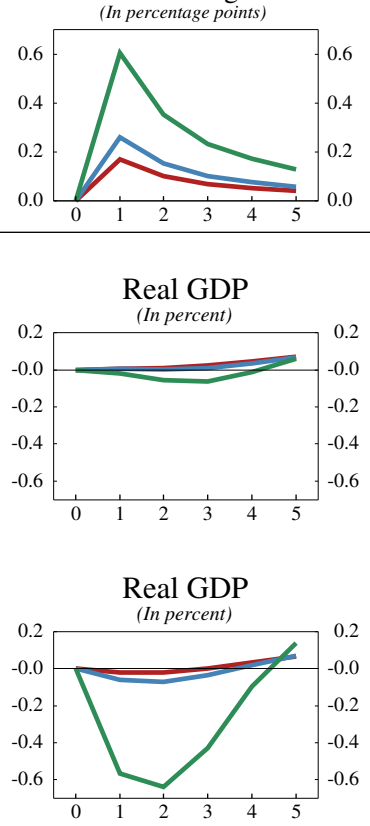

Corporate Net Worth (In percent)

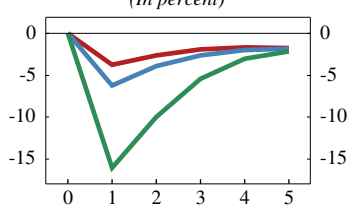

Rest of the World: Model Without Financial Accelerator

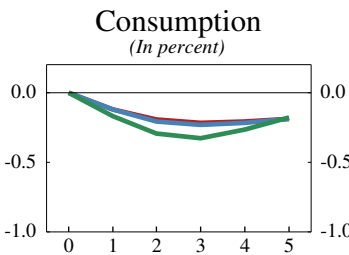

Rest of the World: Model With Financial Accelerator External Financing Premium

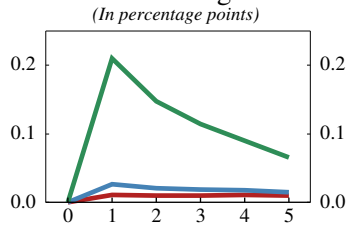

Consumption

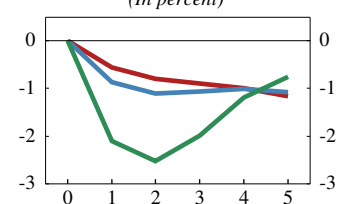

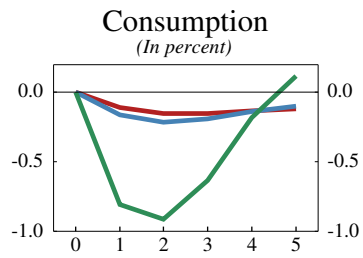
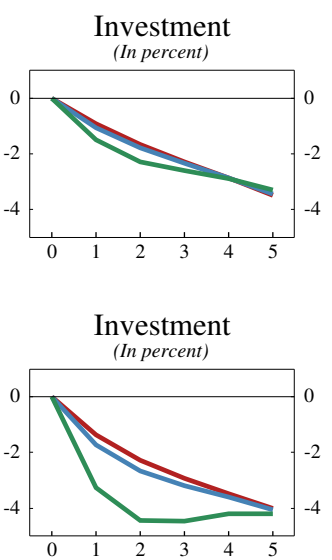
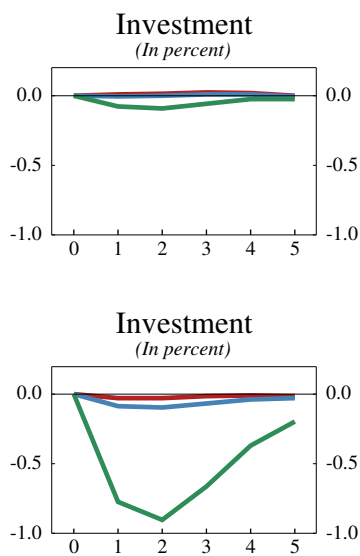
Figure 4: U.S. Persistent Increase in Borrower Riskiness (Deviation from Baseline)

Immediate Policy Interest Rate Response

Unchanged Policy Interest Rate for One Year

_ Unchanged Policy Interest Rate for Two Years
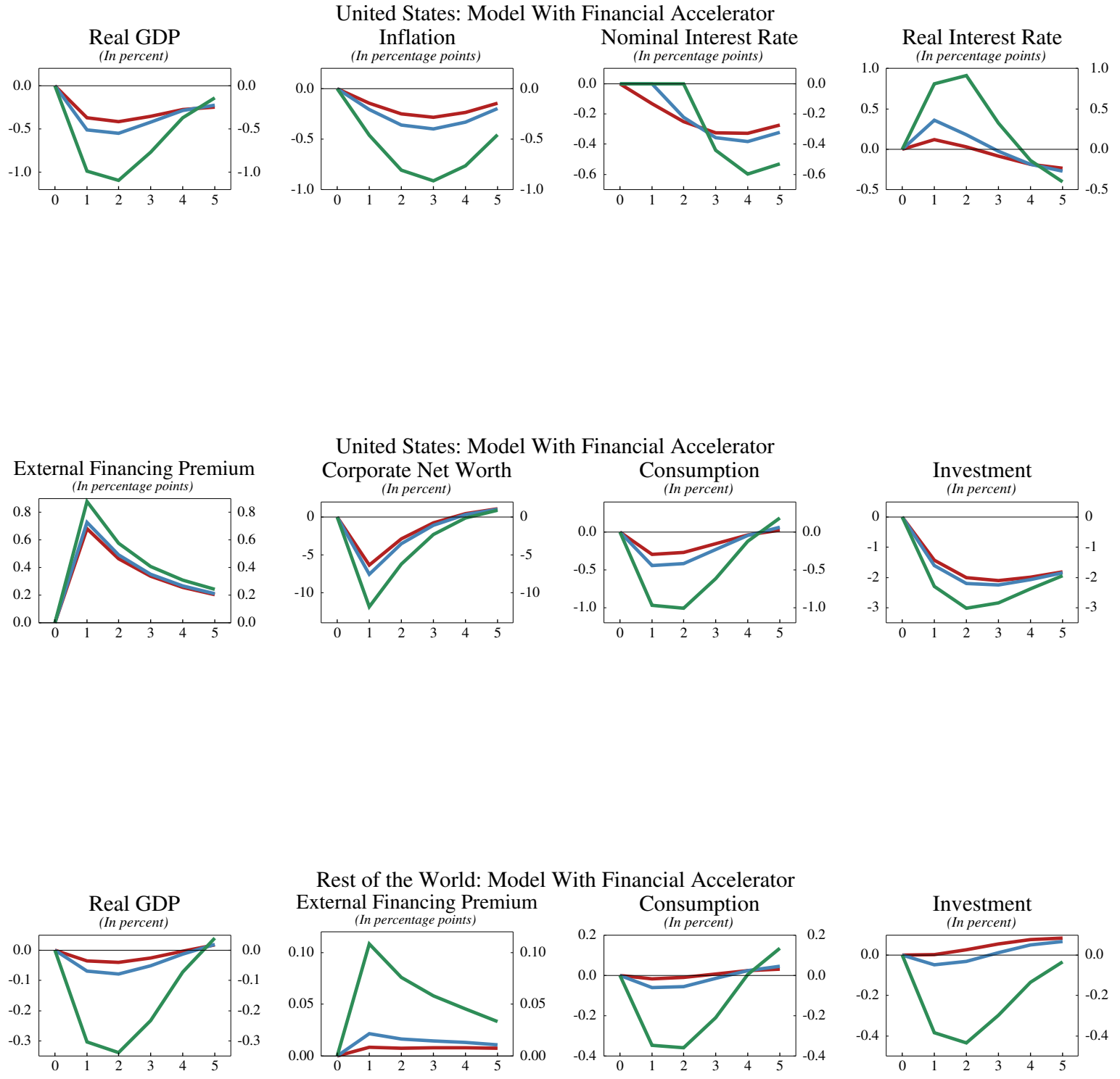

Rest of the World: Model With Financial Accelerator
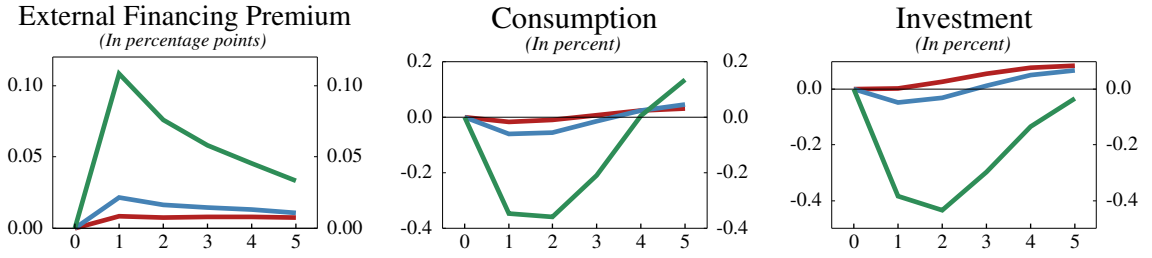
Figure 5: U.S. Fiscal Stimulus, Instrument=Gov't Investment (Deviation from Baseline)

Immediate Policy Interest Rate Response

Unchanged Policy Interest Rate for One Year

_ Unchanged Policy Interest Rate for Two Years

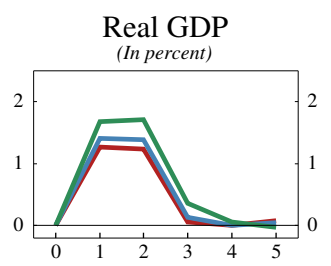

United States: Model Without Financial Accelerator

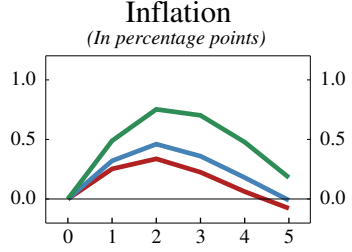

Nominal Interest Rate
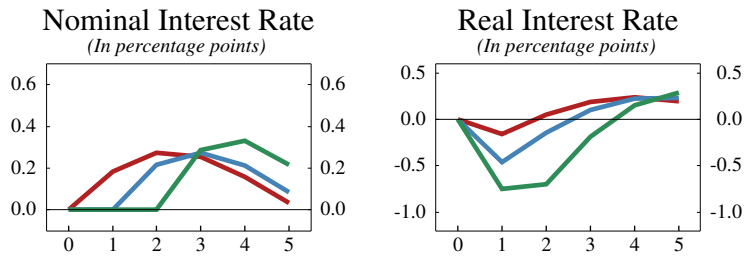

United States: Model With Financial Accelerator
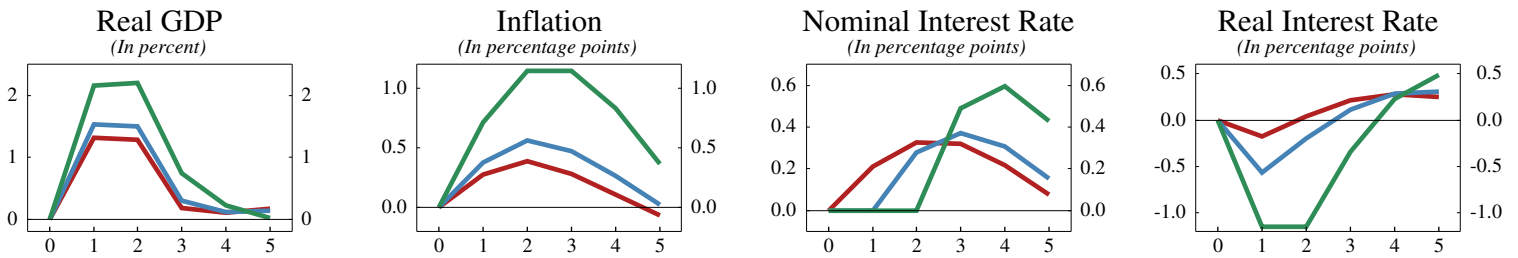

United States: Model Without Financial Accelerator
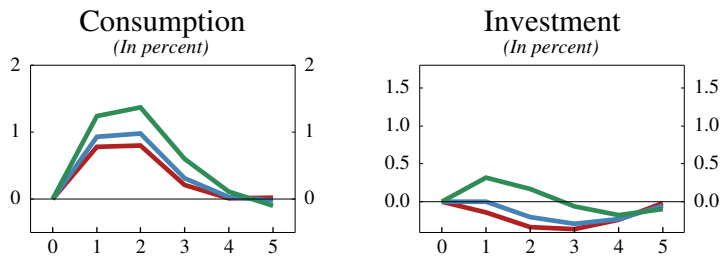

United States: Model With Financial Accelerator

External Financing Premium

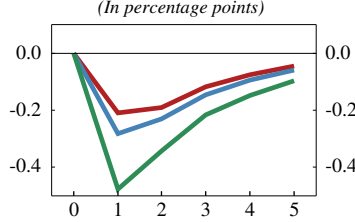

Corporate Net Worth
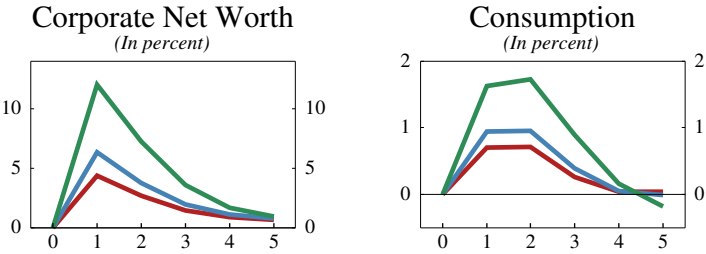

Rest of the World: Model Without Financial Accelerator

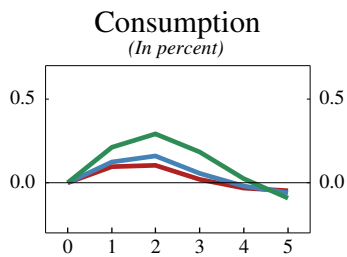

Rest of the World: Model With Financial Accelerator
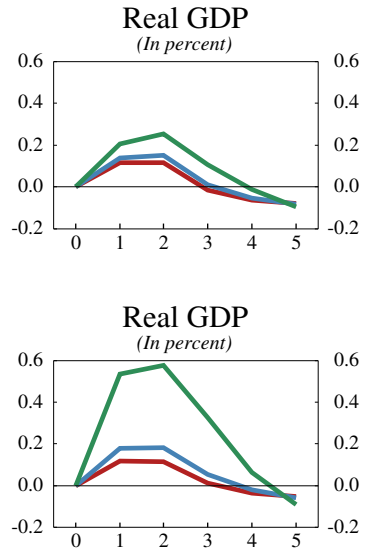

External Financing Premium
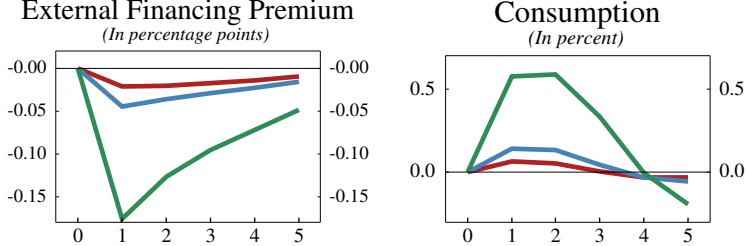
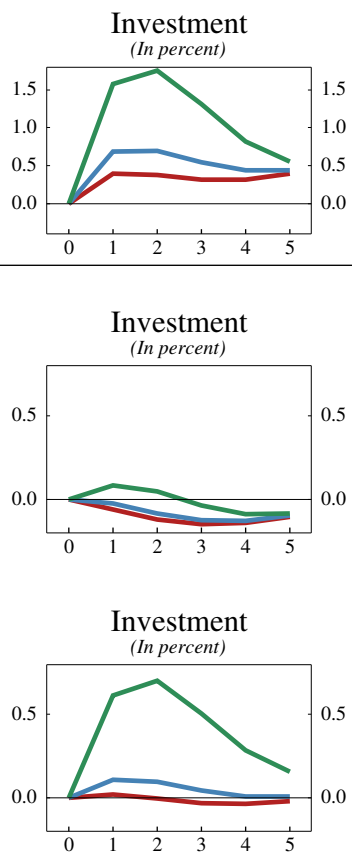
Figure 6: U.S. Fiscal Stimulus, Instrument=General Transfers (Deviation from Baseline)

Immediate Policy Interest Rate Response Unchanged Policy Interest Rate for One Year _ Unchanged Policy Interest Rate for Two Years
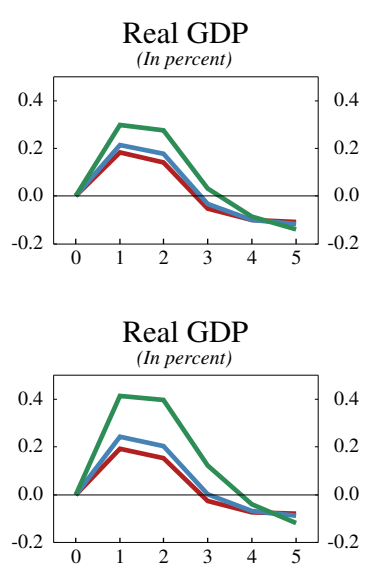

External Financing Premium
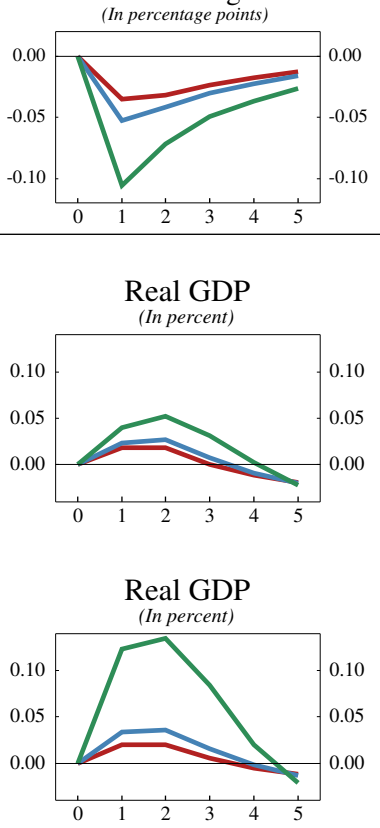

United States: Model Without Financial Accelerator Inflation
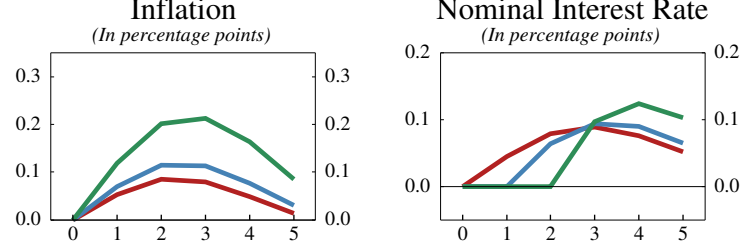

United States: Model With Financial Accelerator
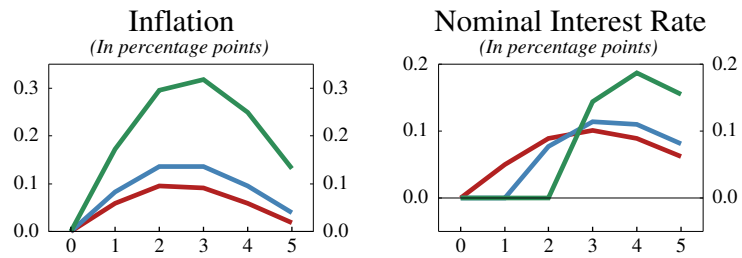

United States: Model Without Financial Accelerator

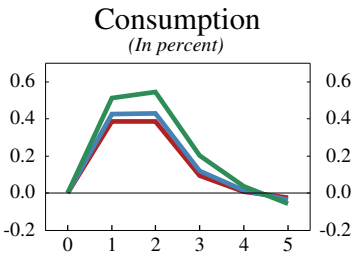

United States: Model With Financial Accelerator Corporate Net Worth
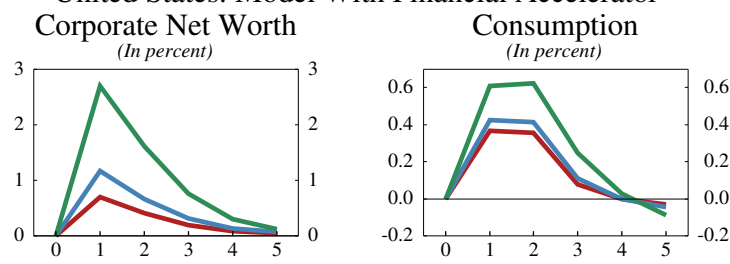

Rest of the World: Model Without Financial Accelerator

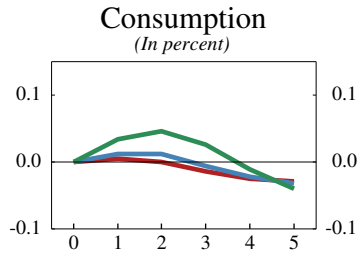

Rest of the World: Model With Financial Accelerator External Financing Premium
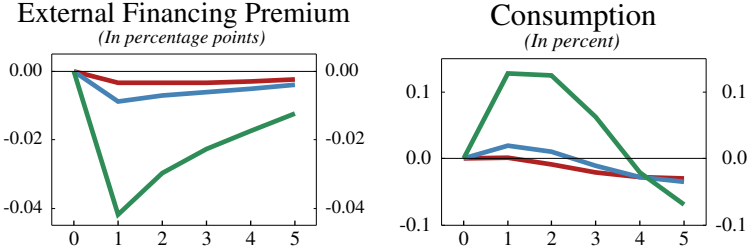
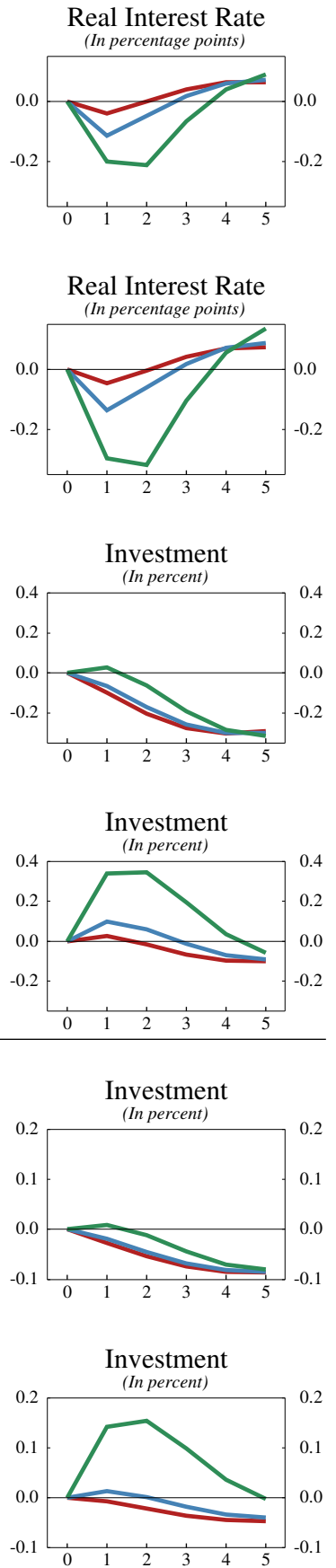
Figure 7: U.S. Fiscal Stimulus, Instrument=Targeted Transfers (Deviation from Baseline)

Immediate Policy Interest Rate Response

Unchanged Policy Interest Rate for One Year

_ Unchanged Policy Interest Rate for Two Years

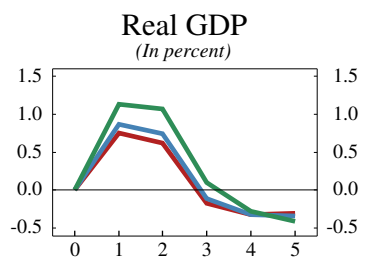

United States: Model Without Financial Accelerator

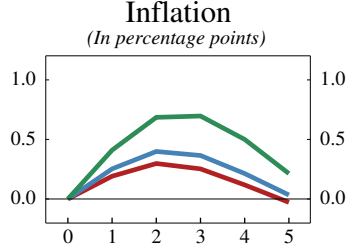

Nominal Interest Rate
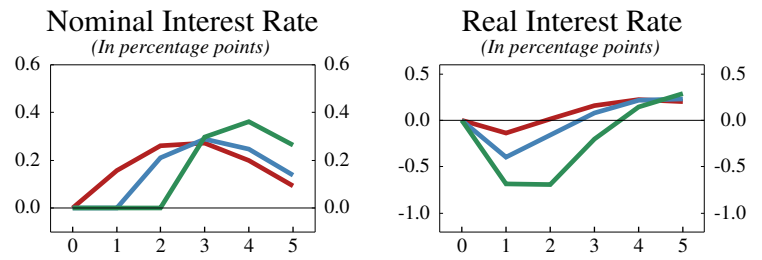

United States: Model With Financial Accelerator
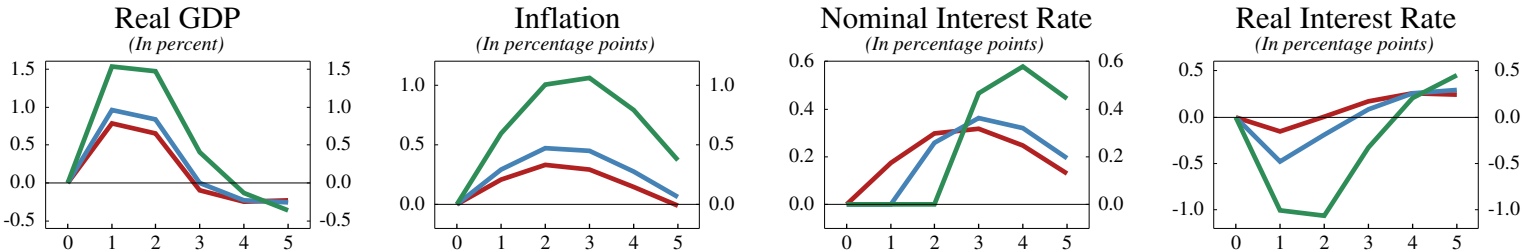

United States: Model Without Financial Accelerator

Consumption
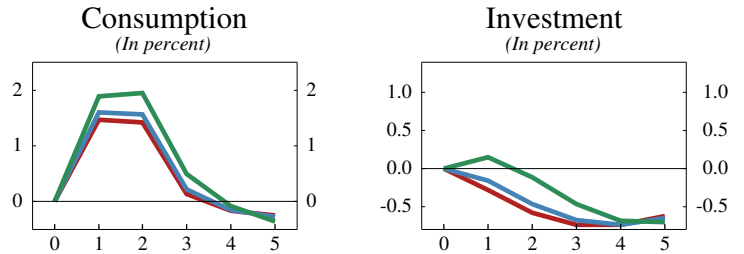

United States: Model With Financial Accelerator

External Financing Premium
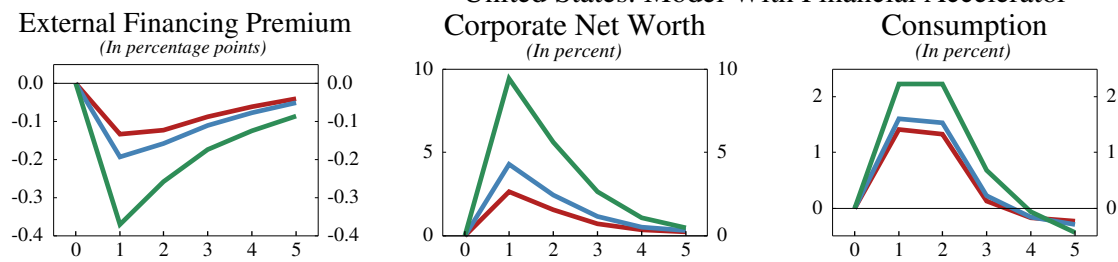

Rest of the World: Model Without Financial Accelerator

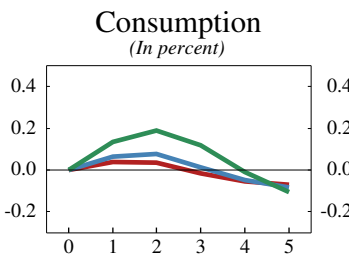

Rest of the World: Model With Financial Accelerator

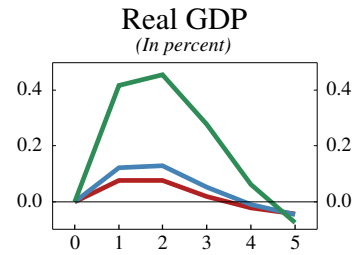

External Financing Premium

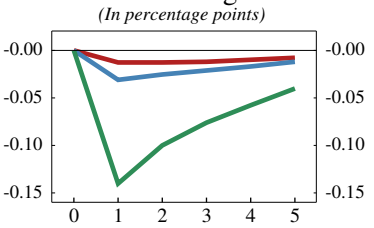

Consumption

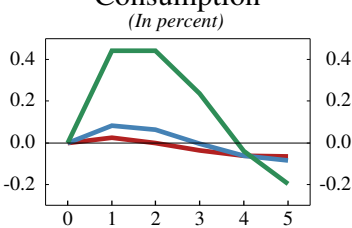

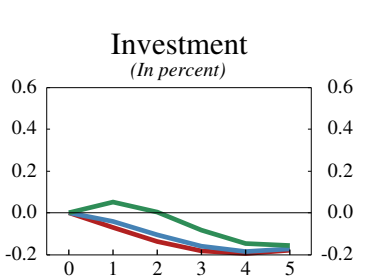
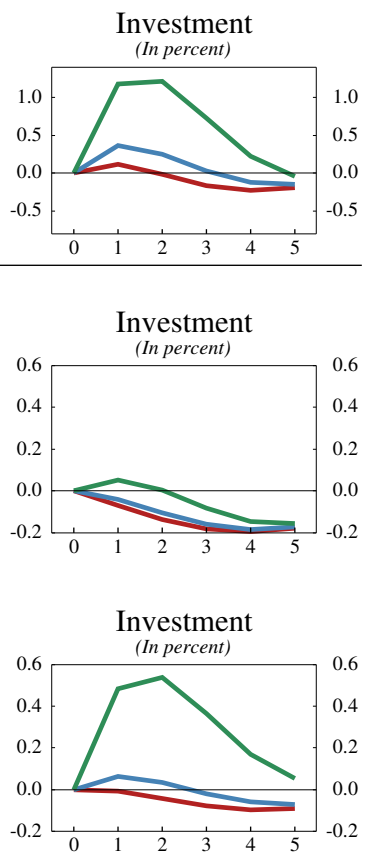
Figure 8: U.S. Fiscal Stimulus, Instrument=Labor Income Tax (Deviation from Baseline)

Immediate Policy Interest Rate Response Unchanged Policy Interest Rate for One Year __ Unchanged Policy Interest Rate for Two Years
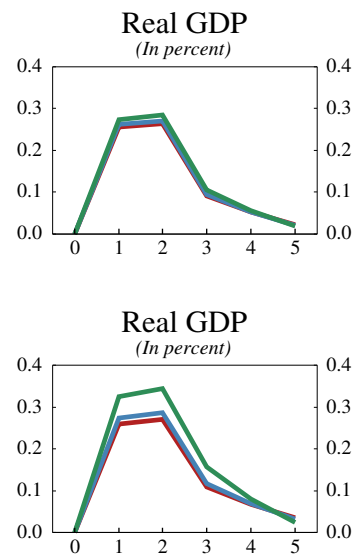

External Financing Premium
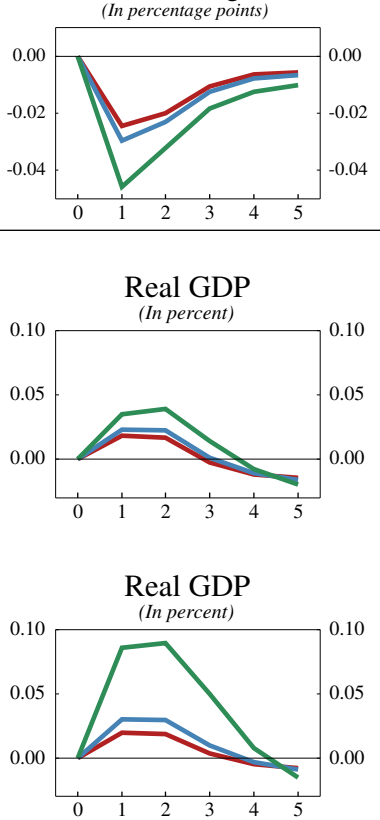

United States: Model Without Financial Accelerator

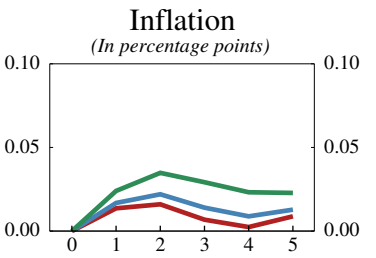

Nominal Interest Rate

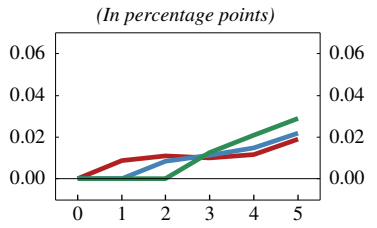

United States: Model With Financial Accelerator
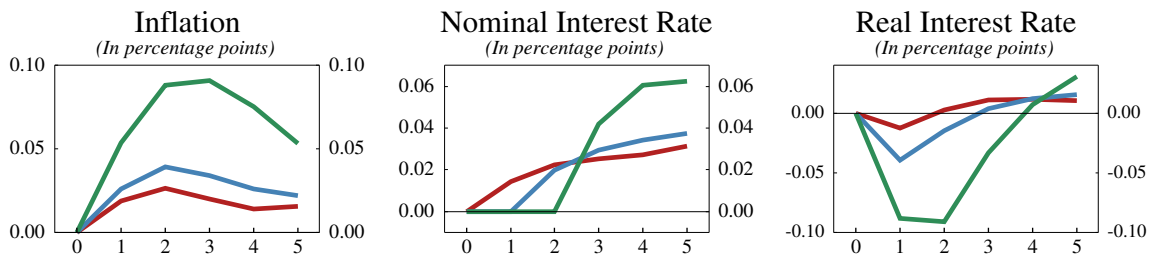

United States: Model Without Financial Accelerator

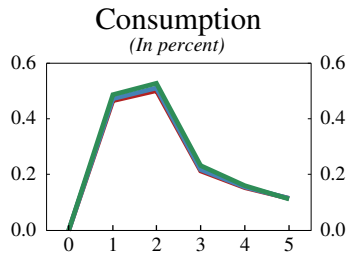

United States: Model With Financial Accelerator Corporate Net Worth
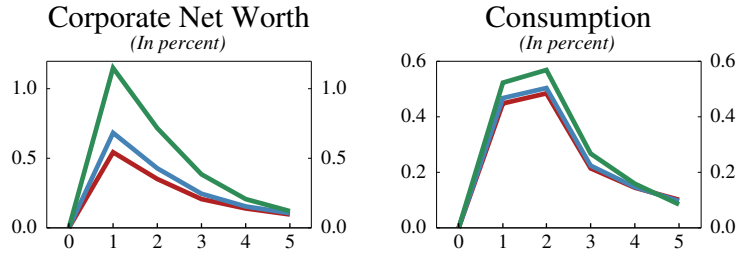

Rest of the World: Model Without Financial Accelerator

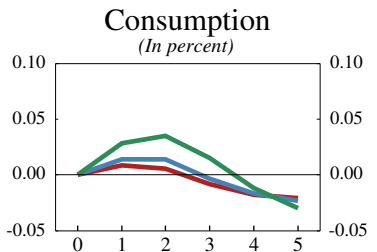

Rest of the World: Model With Financial Accelerator External Financing Premium
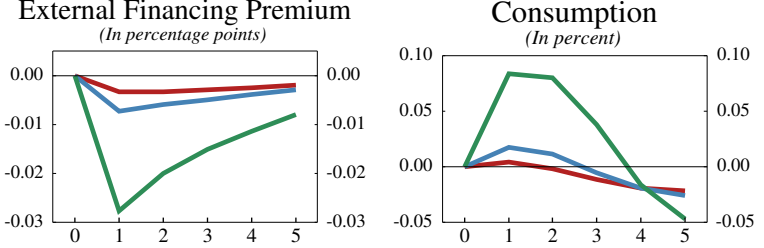
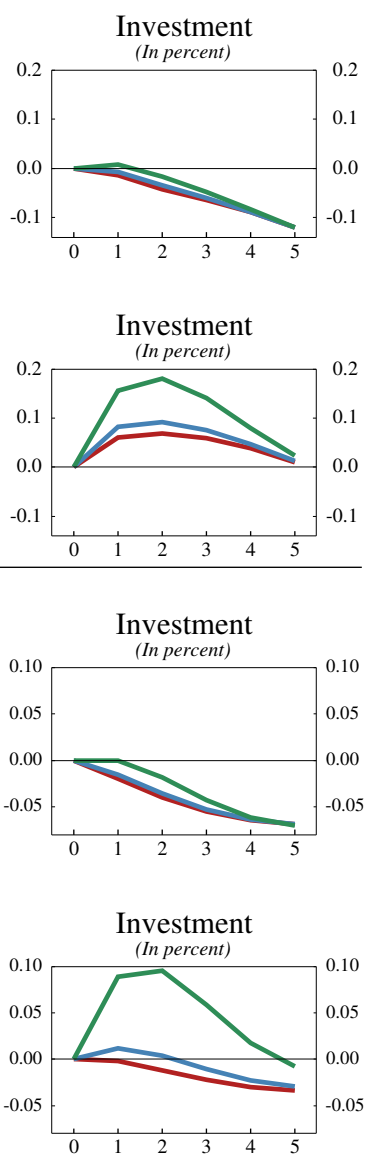
Figure 9: Dynamic Effects of a 10 Percentage Point Increase in the Debt to GDP Ratio
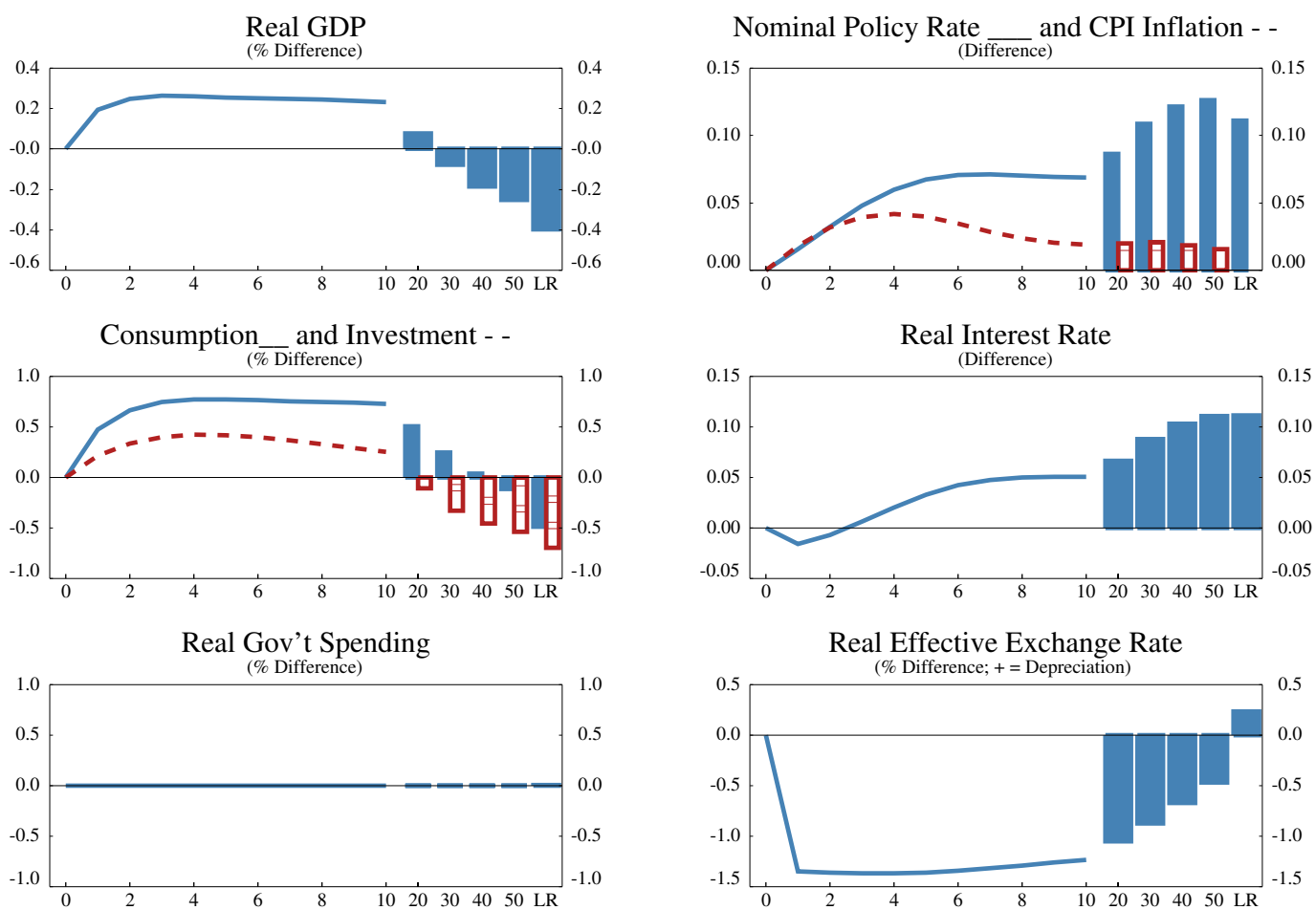

TB/GDP _, CA/GDP - -

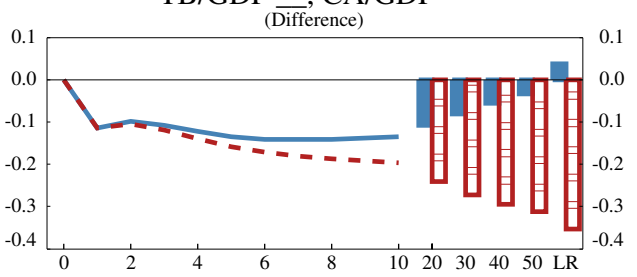

Labor Income Tax Rates

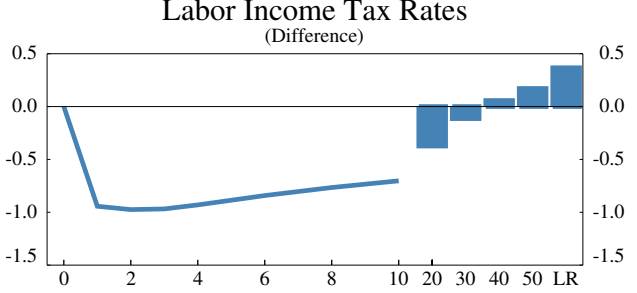

Government Deficit/GDP

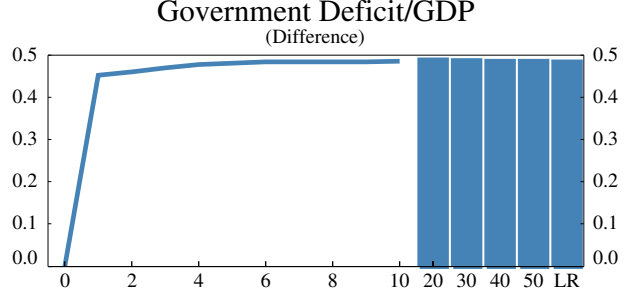

Government Debt Ratio

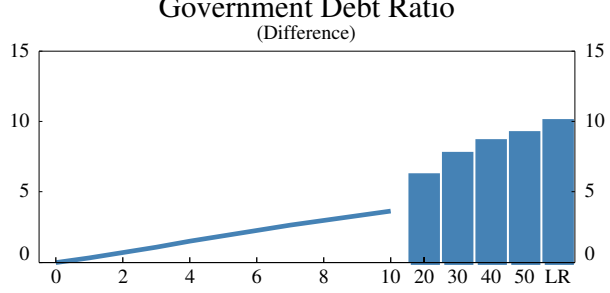

Private Savings/GDP
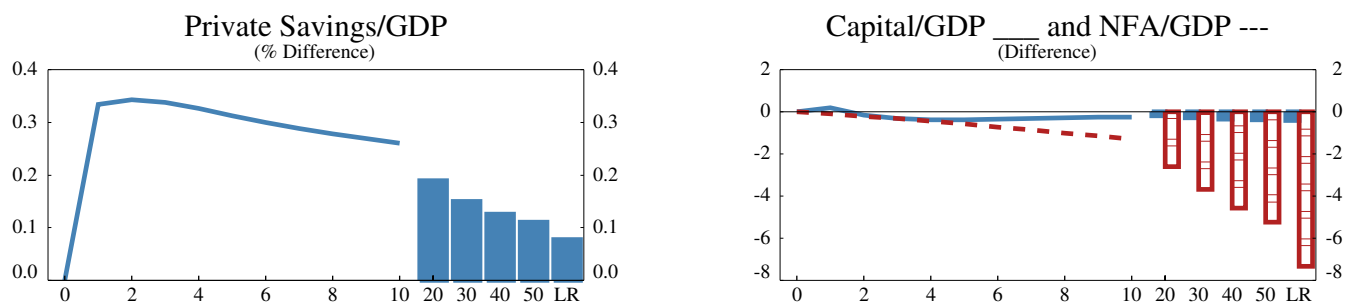
Table 1: GDP Effects of G-20 Fiscal Stimulus (Percent Deviation from Baseline)

Stimulus in:

All U.S. Euro Area Japan Em.Asia RoW

Model without Financial Accelerator

Effects on GDP Level in 2009

World

$1.6 \quad 0.4$

0.1

0.1

0.7

0.3

United States

$1.4 \quad \mathbf{1 . 1}$

0.0

0.0

0.2

0.1

Euro Area

$0.7 \quad 0.0$

0.5

0.0

0.1

0.1

Japan

$1.8 \quad 0.1$

0.0

$\mathbf{1 . 5}$

0.2

0.0

Emerging Asia

$2.6 \quad 0.4$

0.1

0.1

2.0

0.2

Remaining Countries

$1.4 \quad 0.2$

0.1

0.1

0.4

0.8

Effects on GDP Level in 2010

World

$1.3 \quad 0.4$

0.1

0.1

0.6

0.2

United States

$1.2 \quad \mathbf{1 . 0}$

0.0

0.0

0.2

0.1

Euro Area

$0.6 \quad 0.0$

0.3

0.0

0.1

0.1

Japan

Emerging Asia

$\begin{array}{ll}0.6 & 0.1\end{array}$

0.0

1.3

0.3

0.0

$2.2 \quad 0.4$

0.1

0.1

1.7

0.1

Remaining Countries

$1.1 \quad 0.2$

0.1

0.1

0.5

0.5

Model with Financial Accelerator

Effects on GDP Level in 2009

World

United States

$2.1 \quad 0.7$

0.2

0.2

0.8

0.5

Euro Area

1.9

$\mathbf{1 . 5}$

0.1

0.1

0.3

0.2

Japan

$0.9 \quad 0.1$

0.6

0.0

0.2

0.2

Emerging Asia

$2.4 \quad 0.2$

0.0

$\mathbf{1 . 8}$

0.4

0.1

$3.1 \quad 0.8$

0.1

0.1

2.1

0.3

Remaining Countries

$2.0 \quad 0.5$

0.2

0.1

0.7

1.0

Effects on GDP Level in 2010

World

$\begin{array}{ll}1.9 & 0.7\end{array}$

0.2

0.2

0.8

0.4

United States

$\begin{array}{ll}1.8 & \mathbf{1 . 4}\end{array}$

0.1

0.1

0.3

0.2

Euro Area

$0.7 \quad 0.1$

0.4

0.0

0.2

0.1

Japan

2.2

0.1

1.6

0.4

0.1

Emerging Asia

$2.7 \quad 0.8$

0.1

0.1

1.7

0.2

Remaining Countries

$1.8 \quad 0.5$

0.2

0.1

0.7

0.7 
Table 2: Effects of a Permanent 10 Percentage Point Increase in the U.S. Government Debt to GDP Ratio (Deviation from Baseline)

U.S. RoW Global

Financed by a Cut in General Transfers

Real GDP (Percent)

Real Interest Rate (Percentage points)

Current Account to GDP (Percentage points)

Investment (Percent)

Goverment Deficit to GDP (Percentage points)

Private Saving to GDP (Percentage points)

$\begin{array}{rrr}-0.27 & -0.20 & -0.21 \\ 0.10 & 0.10 & 0.10 \\ -0.32 & 0.10 & \\ -0.54 & -0.47 & -0.48 \\ 0.48 & 0.00 & 0.11 \\ 0.12 & 0.05 & 0.06\end{array}$

Financed by an Increase in Labor Income Taxes

Real GDP (Percent)

$\begin{array}{lll}-0.43 & -0.24 & -0.28\end{array}$

Real Interest Rate (Percentage points)

0.11

$0.11 \quad 0.11$

Current Account to GDP (Percentage points)

$-0.36$

0.12

Investment (Percent)

$-0.73$

$-0.54 \quad-0.58$

Goverment Deficit to GDP (Percentage points)

0.48

$0.00 \quad 0.11$

Private Saving to GDP (Percentage points)

0.07

$0.05 \quad 0.06$

Labor Income Tax Rate (Percentage points)

0.41

$0.00 \quad 0.09$

Financed by an Increase in Capital Taxes

Real GDP (Percent)

$-0.6$

$-0.25$

$-0.34$

Real Interest Rate (Percentage points)

0.10

$0.10 \quad 0.10$

Current Account to GDP (Percentage points)

$-0.30$

0.10

Investment (Percent)

$-1.80$

$-0.50$

$-0.79$

Goverment Deficit to GDP (Percentage points)

0.48

$-0.00$

0.11

Private Saving to GDP (Percentage points)

$-0.02$

0.05

0.03

Capital Tax Rate (Percentage points)

1.25

0.00

0.28

Financed by an Increase in Consumption Taxes

Real GDP (Percent)

$-0.34$

$-0.21$

$-0.24$

Real Interest Rate (Percentage points)

0.10

0.10

0.10

Current Account to GDP (Percentage points)

$-0.33$

0.11

Investment (Percent)

$-0.61$

$-0.49$

$-0.51$

Goverment Deficit to GDP (Percentage points)

0.48

$-0.00$

0.11

Private Saving to GDP (Percentage points)

0.11

0.05

0.06

Consumption Tax Rate (Percentage points)

0.32

0.00

0.07 